\title{
The rise and fall of Argentina
}

\author{
Rok Spruk* ${ }^{*}$
}

*Correspondence:

rok.spruk@ef.uni-lj.si

School of Economics

and Business, University

of Ljubljana, Kardeljeva

ploscad 27, 1000 Ljubljana,

Slovenia

\begin{abstract}
I examine the contribution of institutional breakdowns to long-run development, drawing on Argentina's unique departure from a rich country on the eve of World War I to an underdeveloped one today. The empirical strategy is based on building a counterfactual scenario to examine the path of Argentina's long-run development in the absence of breakdowns, assuming it would follow the institutional trends in countries at parallel stages of development. Drawing on Argentina's large historical bibliography, I have identified the institutional breakdowns and coded for the period 1850-2012. The synthetic control and difference-in-differences estimates here suggest that, in the absence of institutional breakdowns, Argentina would largely have avoided the decline and joined the ranks of rich countries with an income level similar to that of New Zealand.
\end{abstract}

Keywords: Long-run development, New institutional economics, Political economy, Argentina, Applied econometrics

JEL Classification: C23, K16, N16, N46, O43, O47

\section{Introduction}

On the eve of World War I, the future of Argentina looked bright. Since its promulgation of the 1853 Constitution, Argentina had experienced strong economic growth and institutional modernization, which had propelled it into the ranks of the 10 wealthiest countries in the world by 1913. In the aftermath of the war, Argentina's income per capita fell from a level approximating that of Switzerland to its current middle-income country status. Although numerous theories have been suggested to explain the swift decline, the general consensus highlights the fundamental importance of institutional environment in shaping the path of economic growth and development (North 1990; Weingast 1997). Although the literature has provided a great deal of evidence, the counterfactual scenario to Argentina's path to underdevelopment remains poorly understood. This paper exploits the temporal variation in institutional breakdowns to consistently estimate the contribution of de jure and de facto political institutions to long-run development, drawing on Argentina's extensive historical bibliography (Rosa 1965; Elizagaray 1985; Waisman 1987; Sábato 1988; Acemoglu and Robinson 2006b).

This paper addresses Argentina's economic development in a long-term historical perspective from its rapid growth takeoff during the Bellé Époque and its subsequent infamous transition from a rich country in early twentieth century to the underdeveloped one down to the present. In this respect, this paper highlights the role and pivotal

(c) The Author(s) 2019. This article is distributed under the terms of the Creative Commons Attribution 4.0 International License (http://creativecommons.org/licenses/by/4.0/), which permits unrestricted use, distribution, and reproduction in any medium, provided you give appropriate credit to the original author(s) and the source, provide a link to the Creative Commons license, and indicate if changes were made. 
importance of institutional framework for sustained long-run growth and development. Drawing on the Argentina's infamous transition to an underdeveloped country, it shows how the absence of broad-based de jure and de facto political institutions creates the conditions for economic stagnation, which can be very hard to overcome regardless of the quality of policy-making. Using the case of Argentina, the paper shows that either a transition to dictatorship or the transition to democracy can produce negative effects on long-run growth if the de facto political institutions such as a broad-based access to collective action for non-elites do not support the de jure institutional changes.

Numerous theories have been used to explain Argentina's transition from a rich country to the underdeveloped one. Not everyone agrees that low-quality institutional framework per se is the root cause of Argentina's underdevelopment. The general thrust of these theories emphasizes the role of the closing of the frontier expansion, differences in the political traditions linked to large-scale nineteenth century immigration, immigration policies, underinvestment in human capital, the comparative advantage in agriculture and its adverse implications for technology, and the role of culture acting as a brake rather than filer in the process of long-run development.

Like Australia and Canada, Argentina was an exporter of primary goods, and until the mid-twentieth century, it followed a development path similar to theirs. Compared with other areas in Latin America, Argentina had a small indigenous population; a low population density; and a favorable stock of natural resources, which precipitated sizable export-driven growth despite the country's geographic isolation from key international markets (Gallo 1983; Duncan and Fogarty 1984; Di Tella and Platt 1986). The question remains, what caused a society that achieved astonishing wealth within 50 years following its independence from Spain to embark on a path of comparative decline? Sanz-Villarroya (2005) identified 2 years of structural break in Argentina's development path compared with those of Australia and Canada: 1896 and 1899. Those years marked important points in Argentina's long-lasting decline in comparison with the two countries.

In a comparative perspective, Argentina's institutional development differed from the United States, Canada or Australia in several key dimensions. After the 1853 Constitution, Argentina embarked on the path of institutional modernization associated with a rapid economic growth fueled by large-scale immigration from Europe and elsewhere. The 1853 Constitution enshrined universal suffrage which had been enforced in 1912 following Sáenz Peña Law. But compared to U.S, Canada and Australia, Argentina never finished the transition to the open democracy supported by the rule of law. When the military formally broke the constitutional order in 1930, Argentina embarked on the path of unstable institutional development frequent back-and-forth transitions between dictatorship and democracy. Instead of embarking on the path to sustained institutional development, Argentina underwent a tumultuous electoral fraud with a near erosion of the system of checks and balanced that precipitated the rise of populist leaders, like Juan Péron, to power. Unstable de jure and de facto institutional framework failed to promulgate growth-enhancing economic policies. Instead, it molded government-backed favoritism of dominant interest groups and encouraged pervasive rent-seeking instead of productive economic activity. On the balance, such institutional framework condemned Argentina to decades of stagnant productivity and poor economic growth. 
This paper looks at 28 countries in the period 1850-2012 and constructs the latent indices of de jure and de facto political institutions using several existing datasets such as Marshall et al. (2013) and Vanhanen (2000, 2003). Deploying a structural model of long-run development with time-varying de jure and de facto political institutions and a series of time-invariant covariates, this paper estimates the contribution of de jure and de facto political institutions to long-run development conditional on the confounding effects previously identified in the literature. The counterfactual scenario is built by constructing an alternative de jure and de facto institutional series in the absence of institutional breakdowns. The synthetic control and difference-in-differences estimates suggest that had such breakdowns not occurred and had Argentina followed the institutional trends of its nearest-counterpart countries, it would be among the richest countries today. We find that making de jure and de facto political institutions more inclusive for the non-elites is associated with an increase in per capita income between 1.8 and 2.6 percent, ceteris paribus. The estimated effect of de jure and de facto political institutions on long-run growth is robust across multiple specification checks, and does not disappear once the confounding effects of physical capital accumulation and human capital investment in the standard Cobb-Douglas production function setup are appropriately taken into account.

The rest of the paper is organized as follows. Section 2 presents the historical background behind Argentina's institutional breakdowns and long-run decline. Section 3 presents the theoretical framework. Section 4 discusses the underlying empirical design. Section 5 presents the data used in the empirical analysis. Section 6 provides results and counterfactual estimates. Section 7 presents the paper's conclusions.

\section{Institutional breakdowns and Argentina's long-run decline}

This section briefly discusses the history and role of institutional breakdowns in Argentina's long-run development path, drawing on Argentina's colonial history, postindependence economic development (Belle Époque), and the subsequent institutional breakdowns.

\subsection{Argentina in the shadow of Spanish colonialism}

On the eve of European colonization in 1580, Argentina was a vast tract of fertile land and a social and economic backwater with a temperate climate and a sparse indigenous population. Unlike Mexico and Peru, it never experienced a highly unequal and stratified society, and its social and economic structure closely resembled that of English colonies, which encouraged colonial settlement to a much greater degree than colonists sought resource extraction (Lynch 1955; Garavaglia and Gelman 1995; Azcuy Ameghino 2002; Prado 2009). The northern and southern parts of Argentina differed markedly in their social, economic, and institutional makeup. The northern part, having a greater indigenous population density, was swiftly integrated into the Viceroyalty of Peru to provide a source of cheap labor for the Potosí mines and for large landowners; whereas, the southern part was never integrated into the colonial economy (Kovac and Spruk 2017). The institutional framework of preindependence Argentina was a prototype of Spanish colonial structure (Shumway 1991; Ribas 2000). The Spanish elites immediately instituted the Repartimiento, an exploitative labor system that rested on a forced distribution of 
goods and services to the local population at heavily inflated prices, keeping the nonelite population in heavy and permanent debt (Baskes 2000). Such exploitation and pervasive rent-seeking (Golte 1980) encouraged various forms of servitude, critically depressed the formation of human capital, and led to the near absence of economic opportunities for nonelites (Moreno Cebrián 1976; Andrien 1982, 1984; de Velasco 1983; Mukerjee 2008).

For more than two centuries, from 1580 to 1816, the Royal Audience (Audiencia Real) of Charcas served as a prototype superinstitution with combined legislative, executive, and judicial powers over the provinces of Río de la Plata (Mirow 2004). Although the Audience was originally designed to uphold law and order and curb the abuses of powerholders, massive debts as a result of high-cost wars in Europe prompted the Spanish Crown to launch the sale of public offices, including posts to the Royal Audience, starting in 1687 (Burkholder and Chandler 1977; Guardado 2016). The selling of offices led to the colonial state's capture by powerful Creole elites and the dilution of royal authority as the ultimate check on abuses of power by local strongmen. Office sales characterized more than a century of Argentina's colonial history and gradually evolved into the entrenchment of rich and powerful families and local military strongmen (caudillos). Intimidation, bribery, and fraud became the cornerstones of the distribution of political and economic power, cementing the intellectual foundations of the independence movement against Spain in the early nineteenth century.

\subsection{Institutional change, economic growth, and the triumph of Argentina}

After suffering two centuries of economic stagnation, declaring independence from Spain in 1816, and experiencing a civil war between the Unitarian Party (Partido Unitario) and the Federalist Party (Partido Federal), Argentina promulgated a constitution in 1853. The constitution set the foundation for a political system following James Madison's model of the republican division of powers constituting an executive government, two legislative chambers, and an independent judiciary to counterbalance the power of the legislative and executive branches (Eder 1949; Vittadini Andres 1999; Gomez 2000). In 1862, Argentina became a federation (Rennie 1945; Romero 2013). The promulgation of the 1853 Constitution can be viewed as a departure from the colonial wars and anarchy to form an institutional framework conducive to sustained economic growth and development (Halperín Donghi 1970; Haring 1972). The constitution appeared to end the political instability and the strongman rule of local caudillos, promised to keep civil disorder to a minimum, and sought to ensure peaceful power transfers (Cortés Conde 1998a, b; Adelman 1999).

New commercial and civil codes were enacted in 1862 and 1871, respectively, under the extensive influence of Roman law, the Napoleonic Code, and the liberal principles of the nineteenth century (Kelly 1992; Berkowitz et al. 2003a, b; Miller 2003). Decisive shifts toward enhanced state capacity were marked by the 1884 general education law and the development of a modern railway system, along with the modernization of the postal system. Such policies were pivotal in sowing the seeds of Argentina's Belle Époque from 1875 onward (Taylor 1992; Przeworski and Limongi 1997; della Paolera and Taylor 1999; Sanz-Villarroya 2007; Prados de la Escosura and Sanz-Villarroya 2009).

After 1862, Argentina experienced unprecedented economic growth brought about by flows of foreign capital and extensive immigration, with Italy, Spain, and 
Central Europe providing the largest supply of newcomers (Germani 1966; SánchezAlonso 2000). In less than a quarter of a century, Argentina moved from the economic and social backwater that characterized the provinces of Río de la Plata until 1852 to the region's economic powerhouse (Di Tella et al. 2013). By 1896, Argentina had achieved remarkable parity with the United States in terms of per capita income. By 1913, its income per capita was at the same level as Western Europe's and exceeded that of Italy, Spain, and Portugal by a wide margin (Maddison 2007a, b; Bolt and van Zanden 2014). By the dawn of the twentieth century, Argentina seemed solidly positioned in the ranks of rich countries (Acemoglu and Robinson 2012). To have said that Argentina was set to become an underdeveloped country would have been considered laughable given that it had one of the highest literacy rates in the world (Díaz Alejandro 1970).

Between 1850 and 1930, Argentina's development path differed drastically from that of its Latin American peers and approached the levels of Western Europe and North America at that time (Fukuyama 2008). However, today, Argentina's per capita income level is comparable to that of Turkey and Russia. For most of the second half of the twentieth century, Argentina was plagued by military coups, countercoups, violent oscillations between the Left and the Right, unprecedented institutional instability, and frequent turmoil that brought it to the edge of civil war several times (O'Donnell 1973). In 1860, Argentina would have needed about 55 years to catch up to the Swiss level of per capita income. Today, if it continued its current growth trajectory, it would need more than 90 years to do so. The obvious question is what went wrong?

During the Infamous Decade of the 1930s, a conservative political alliance known as the Concordancia perpetrated electoral fraud to keep its hold on power. Recognition of the military regime by the Supreme Court, the court's silence regarding the systematic exercise of electoral fraud, and the redistributional tendencies of the 1912 Sáenz Peña Law paved the way for the populist policies and Peronist institutional reforms (Germani 1973; Waisman 1987; Sábato 1988; Romero 1998). These reforms enshrined government-backed favoritism of dominant interest groups and encouraged widespread rent-seeking instead of productive economic activity. Peronist economic policies set the foundations for volatile policies and unstable institutional development by redistributing rents to the privileged and to well-organized interest groups, condemning Argentina to decades of stagnant productivity and poor economic growth. Initially, the nondemocratic rule of the conservative Concordancia, which was based on electoral fraud, was accompanied by inward-looking industrialization, which was based on import substitution. Following Juan Perón's rise to power, populist-style income and wealth redistribution policies and further erosion of the system of checks and balances proved detrimental to Argentina's institutional development and its path of long-run growth (Gibson 1997). The question remains whether Argentina would have continued to experience long-run growth and institutional development had it not adopted policies that undermined the rule of law and caused the general breakdown of contracting and property rights-related institutions and had it instead maintained the same degree of institutional stability as the United States, Canada, and Australia. 


\subsection{Institutional breakdowns, the reversal of democracy, and Argentina's decline}

In stark contrast to the United States, post-1853 Argentine constitutionalism lacked appropriate informal institutional underpinnings (Ots Capdequí 1943). Although the 1853 Constitution enshrined the principle of limited government with checks and balances (Iaryczower et al. 2002; Jones et al. 2002; Spiller and Tommasi 2003), Argentina's historical norm has been one of poorly limited government, persistent militarism, amateur self-government, political absolutism (García Hamilton 2005), inherent tensions between fundamentally conflicting traditions, failure to create a common market, difficulties developing procedural institutions as a check on power abuses (Chavez 2004; Alston and Mueller 2006; Alston and Gallo 2010), absence of Marbury v. Madison-style judicial review ${ }^{1}$ (Miller 1997), and a traditional disrespect for law and order (Bayle 1952; Zorraquín Becú 1978; Rosenn 1990). Wenzel (2010) suggests that, in its embryonic stage, the 1853 Constitution was an institutional break from Argentina's long history of anarchy and disorder, whereas García Hamilton (2005) suggests that the period from 1907 to 1946 saw the reemergence of colonial traits that had constrained Argentina's growth before its independence from Spain, such as mercantilist state interventions, disregard for the rule of law, and political favoritism. Although the 1853 Constitution set Argentina on an accelerated development path, subsequent breakdowns caused the country to return to its former cultural norms (Rock 1987, 1993). Argentina's institutional culture in the nineteenth century stemmed directly from Spanish colonial antecedents. Under colonial rule, Argentina was unable to forge the customs and norms necessary for a broad-based transition to open-access institutions under a genuine rule of law. ${ }^{2}$ In contrast, at their founding, the United States and other Western offshoots enjoyed a long tradition of local self-government that simply did not exist in Argentina, where political absolutism, regional interests, dirigisme of local caudillos, divide-and-rule politics, and power abuses were the norm (Cantón 1973; Rock 1975, 1987; Halperín Donghi 1995). Despite the legal and economic institutions in place to support economic growth, between 1853 (when Argentina adopted its constitution) and its election of 1914 (the first election under reformed electoral legislation), Argentina was an illiberal democracy at best (Zakaria 1997).

Before the 1914 election, a series of conservative governments secured their hold on power through fraudulent elections and voter intimidation, which primarily took place in the Pampas, the dominant base of the conservative National Autonomist Party (Partido

\footnotetext{
5 U.S. 1 Cranch 137 (1803).

2 Wenzel (2010, 336-37) offers a very clear explanation for the disconnection between the 1853 Constitution with its subsequent amendments and the long tradition of Spanish colonial institutions:

The 1853/60 constitution was accepted by the interior provinces only because it was federalist... But Argentine federalism was different. Although the founding élites of 1853 were mostly federalist, Argentina as a whole never embraced such a belief. Local caudillos, regional interests, and the porteño leadership embraced only a pragmatic federalism, designed to protect their own power from competitors... The political and economic order of the postconstitutional era was decidedly not liberal. Concessions to freedom were calculated, not principled, as the ruling oligarchs shrewdly applied the personal guarantees necessary to attract immigration and capital, while using the state to foment economic growth. From 1853/1860 to the populist takeover of 1916, the constitution was driven and manipulated by the oligarchy. Economic growth of the country was really the economic prosperity for the élite. The system was economically liberal, but not in a civil or political sense... As long as they could stay in power, and as long as the money kept rolling in, the oligarchs maintained the veneer of a liberal order. But as soon as they started to lose power through electoral reform and the subsequent middle class erosion of their power base, and the economy faltered, the proverbial iron fist broke out of the velvet glove, and the military formally broke the constitutional order in 1930.
} 
Autonomista Nacional, or PAN). ${ }^{3}$ Even though the 1853 Constitution enshrined popular participation, voter turnout had been extremely volatile, particularly in Buenos Aires and the Pampas (Sabato 2001). Elections were invariably ritualistic power games, with a minority of the electorate participating (Walter 2002). By the late nineteenth and early twentieth centuries, pressure had mounted for a more open, pluralist, and participatory political system. The rising social discontent revolved around the opposition party, the UCR, which under the leadership of Hipólito Yrigoyen launched several revolts against the government. The UCR was an instrumental player, calling for the establishment of open elections and a secret ballot.

In 1912, the Sáenz Peña Law was passed, introducing the secret ballot and de jure outlawing fraudulent electoral practices (Engerman and Sokoloff 2005). Even though electoral democracy tends to foster political accountability and the rule of law (Knack and Keefer 1995; Weingast 1997; Barro 1999; Maravall and Przeworski 2003; North et al. 2009), it may also encourage the redistribution and erosion of property rights, especially if it is introduced in the context of poverty, low education levels, and near absence of a middle class (Lipset 1959; Acemoglu et al. 2005; Evans and Rose 2007; Glaeser et al. 2007; Mukand and Rodrik 2015; Maseland and Spruk 2017). The Sáenz Peña Law of 1912 was clearly a manifestation of greater political freedom at the expense of economic freedom (Friedman 1962; Kenn Farr et al. 1998; Gwartney et al. 1999; Goel and Nelson 2005).

After passage of the 1912 law, Argentina saw a notable increase in voter registration (Molinelli et al. 1999) and voter turnout (Vanhanen 2000). The 1914 election reshaped the legislature, and Yrigoyen, the populist leader of the UCR who had played a substantial role in the passage of the Sáenz Peña Law, ascended to the presidency in 1916. While in power, President Yrigoyen substantially expanded the size of the bureaucracy and generalized the practice of appointing administrative employees to nonexistent jobs as a reward for political favors. In his first term, a law freezing real estate rent was passed, and the Supreme Court, with only one justice dissenting, affirmed that the law did not violate the constitution. Hence, although the Sáenz Peña Law facilitated some electoral transparency and accountability (Llach 1985; O'Connell 1986; Osiel 1995; Alston and Gallo 2010), it also laid the foundation for populist redistribution of income and wealth (Acemoglu and Robinson 2000, 2001) and for rent-seeking (Mohtadi and Roe 2003; Spinesi 2009), both of which curtail economic freedom and constrain economic growth (Olson 1982; Murphy et al. 1993; Alesina and Rodrik 1994; Sturzenegger and Tommasi 1994; Saint Paul and Verdier 1996; Przeworski and Limongi 1997; Aghion et al. 1999; Zweimüller 2000).

Unable under the Argentine constitution to run for reelection himself in 1922, Yrigoyen was succeeded by another UCR leader, Marcelo de Alvear. When de Alvear's term

\footnotetext{
${ }^{3}$ After the presidencies of Bartolomé Mitre (Liberal Party of Corrientes, or Partido Liberal de Corrientes) and Domingo Sarmiento (an independent candidate) ended in 1868 and 1874, respectively, the subsequent presidents were elected from the conservative elites. Their party, PAN, consistently manipulated elections using fraudulent techniques and voter intimidation. An English newspaper in 1890 highlighted the persistence of electoral fraud, describing the rise of Miguel Juárez Celman to the presidential office: "Today, there are dozens of men in government who are publicly accused of malpractice, who in any civilized country would be quickly punished with imprisonment, and yet none of them have been brought to justice. Meanwhile, Celman is at liberty to enjoy the comfort of his farm, and no one thinks to punish him" (Pigna 2016)
} 
expired in 1928, Yrigoyen was elected to a second term. In 1930, however, a military coup under conservative control ousted President Yrigoyen, marking the beginning of the Infamous Decade, when old colonial traits reemerged (Ciria 1974; Bethell 1993). The change in government was accompanied by a radical ideological change, and the institutional environment in the postcoup period leaned heavily toward corporatist principles (Alhadeff 1989; Goldwert 2014), with substantially less economic and political freedom compared to the previous democratic regime. Active and dirigiste state intervention and electoral fraud became the norm (Cantú and Saiegh 2011) with no regard paid to the economic and institutional disadvantages of such actions over the long term. The military regime outlawed political parties, annulled local elections, suspended the 1853 Constitution, and resorted to the extensive use of electoral fraud in the 1931 and 1937 presidential elections (Díaz Alejandro 1970; Cantón 1973; Schilizzi Moreno 1973; Smith 1974; Rouquié 1982; Sanguinetti 1988; Potash 1996; de Privitello and Romero 2000). In 1932, market boards were created to regulate the production of meat, cereals, and a few other products, which further consolidated active and inefficient state intervention in many economic areas.

Conservative rule lingered throughout the 1930s, first under General Agustín Justo, who was elected in 1931 through the efforts of the Concordancia, a political alliance of conservative elites, and then under Presidents Roberto Ortiz and Ramón Castillo, who were also supported by the Concordancia. It was brought to an end by another military coup in 1943, which took place amid a backdrop of electoral fraud and poor labor rights (Owen 1957; Teichman 1981; Pereira 1983; Horowitz 1990; Adelman 1992). The unstable regime that followed led to the emergence of Colonel Juan Perón, who had been placed in charge of the Labor Department and eventually rose to become vice president.

In 1946, Perón was elected president and gained strong popularity (Smith 1969). Perón's presidency precipitated the almost complete demise of the rule of law (Matsushita 1983). A series of institutional breakdowns took place as a result of the clientelist political practices, political favoritism, and unprecedented populist redistribution of income and wealth. Perón and his highly popular wife Eva Perón excused such policies, as well as violence, in the name of social justice (Gerchunoff and Díaz Alejandro 1989; Sachs 1990; Bambaci et al. 2002; Krueger 2002), although the policies interfered heavily with constitutional provisions (Little 1973; Kenworthy 1975; Elizagaray 1985; Rock 1987; Sábato 1988; Spiller and Tommasi 2003). Peronists put Supreme Court justices on political trial, forced their resignation, and replaced them with justices who were friendly to Peronist policies (Fayt 1967). ${ }^{4}$ Peronists viewed the Supreme Court as an ally of the old oligarchy of the infamous decade and as a barrier to their social and economic reforms (Ferrero 1976; Di Tella 1998; Pellet Lastra 2001). They also jailed their political opponents (Murmis and Portantiero 1972; Wynia 1978; Eaton 2002), widened the scope of government activity in the economy through a series of nationalizations, introduced a

\footnotetext{
${ }^{4}$ Before the rise of Perón, Supreme Court turnover mainly occurred when justices died, retired, or voluntarily resigned. The purge of Supreme Court justices during Perón's rule in 1946-55 changed the causes of turnover (Gallo and Alston 2008). Before 1945, 38 changes of justices are recorded, 12 of which are accounted for by retirement, 20 by death, and 6 by voluntary resignation. After Perón's rise to power, 65 changes of justices are recorded. Only four Supreme Court justice changes are accounted for by death and just one by retirement. The remaining 59 changes resulted from voluntary resignation (18 changes), involuntary resignation (20 changes), impeachment ( 4 changes), or forced removal (17 changes).
} 
regulatory framework that distorted property rights and freedom to contract (Buchanan 1985), launched massive government propaganda across Argentine schools to justify their social and economic reforms, ${ }^{5}$ introduced price fixing, and suspended evictions of nonpaying tenants to benefit the constituent renters in rural areas (Roe 1998; Collier and Collier 2004; Mazzuca 2007). Meanwhile, price and rent controls were put in place that undermined property rights and increased transaction costs, the central bank was used to cover provincial debts, a labor court was unconstitutionally introduced, and clientelism became widespread with jobs doled out in nationalized businesses (Samuels and Snyder 2001). The effects were rampant inflation (Potash 1996) and subversive macroeconomic instability (Díaz Alejandro 1970; Rock 1993). In less than 10 years, Peroniststyle favoritism and populism exploited the weakness of the institutional environment (Ilsley 1952; Montaño 1957; Garay 1991; Negretto 2009) by dismantling the rule of law to the point of breakdown (Waisman 1987; Crassweller 1988; Calvo and Murillo 2004; Elena 2007; Alston and Gallo 2010).

The first Perón era ended in 1955. The period between 1955 and the return to democracy in 1983 saw the vicious blend of militarism and absolutism that characterizes military dictatorships. ${ }^{6}$ In 1955, Argentina was on the brink of civil war, and Perón was ousted in a military and civilian uprising. The provisional military regime continued to rely on forced resignations of Supreme Court justices. Numerous import and export restrictions and exchange rate controls were put in place, excused by the regime's incessant reliance on declaring a state of economic emergency. The path to the rule of law, economic liberalization, and open democracy simply failed to gain momentum (Spinelli 2005).

Another military coup took place in 1966, instigating the series of military-appointed presidencies that marked Argentina's decisive turn to an authoritarian-bureaucratic state (O'Donnell 1973; Smulovitz 1991; Szusterman 1993). The prosecution of political opponents (Walter 1969; Díaz Bessone 1986), removal of Supreme Court justices, subjugation of the Supreme Court to the Ministry of Interior by a simple decree, and annulment of the 1853 Constitution only affirmed the persistence of institutional breakdowns (O'Donnell 1973; Brennan and Rougier 2009; Romero 2013). These changes were accompanied by a heavily protectionist economic policy espousing government favoritism (Snow 1965).

Perón returned from exile in 1973 and was elected president, with his third wife, Isabel Martínez de Perón, as vice president. His presidency led to populist-style income and wealth redistribution through social transfers (Lupu and Stokes 2010). As guerrilla battles and civilian violence escalated, the Peróns exploited the fragile institutional environment (Campos et al. 2012) through exclusionary political favoritism based on personal loyalty. In 1974, Perón died, and Isabel Perón became president. She was ousted in 1976

\footnotetext{
${ }^{5}$ One such form of propaganda was the assignment of Eva Perón's autobiography, La Razón de Mi Vida, as compulsory reading in Argentine schools.

${ }^{6}$ Acemoglu and Robinson (2006b, 7) write, "The political history of Argentina reveals an extraordinary pattern where democracy was created in 1912, undermined in 1930, re-created in 1946, undermined in 1955, fully re-created in 1973, undermined in 1976, and finally re-established in 1983. In between were various shades of nondemocratic governments ranging from restricted democracies to full military regimes. The political history of Argentina is one of incessant instability and conflict. Economic development, changes in the class structure and rapidly widening inequality, which occurred as a result of the export boom from the 1880's, coincided with pressure on the traditional political elite to open the system. But, the nature of Argentine society meant that democracy was not stable."
} 
by a military coup. The military junta that came into power used the veneer of an institutional vacuum to commit a series of human rights violations, including the systematic torture of political dissidents, who were held in clandestine jails, and a full ban on political parties and judicial stratification (Di Tella 1983; Munck 1985). Apart from preserving its political power, the junta initiated the breakout of a civil war, with forced disappearances of political opponents, violence against civilians, and subversive militarism (PionBerlin 1985). Without an independent Supreme Court to monitor the executive branch, Argentina abandoned the rule of law and completely dismantled the system of checks and balances (Manzetti 1993; Arceneaux 1997).

This completed Argentina's long decline from a rich country on the eve of the Great Depression to an underdeveloped one. Without a de jure and de facto institutional framework to support low transaction costs and to secure property rights and the rule of law (Scartascini and Tommasi 2012), Argentina saw its status diminish as various shades of weakly democratic and nondemocratic governments used the institutional framework to pursue policies tailored to clientelist interests or directly to benefit those in power via the iron law of oligarchy (Michels 1911). Without an institutional framework to channel conflicts into peaceful resolution by an independent Supreme Court, Argentina transitioned back and forth between democracy and dictatorship (Acemoglu and Robinson 2006b). Since the 1930 military coup, Argentina has never finished the transition to open democracy under the rule of law. Even though Argentina formally transitioned to democracy in 1983, institutional breakdowns emanating from the instability of the Supreme Court, political favoritism, and recurring absolutist rule remain deeply embedded in the political culture and institutional framework, thereby undermining the foundations of long-run growth and development. The economic consequences of the series of prolonged institutional breakdowns-particularly what the long-run development trajectory would have been without the breakdowns-remain an essential empirical question.

\subsection{Transmission mechanisms at work}

Several transmission channels have been proposed to link Argentina's institutional framework to its growth and development outcomes in the twentieth century. Prados de la Escosura and Sanz-Villarroya (2009) suggest that weak contract enforcement and insecure property rights played key roles in Argentina's economic decline in the 20th century. They deploy a structural model of contract-intensive money (CIM) as a rough indicator of contract enforcement and security of property rights based on earlier work by Clague et al. (1999) and show that the associated stock of CIM declined considerably during a period starting after the Great Depression and lasting until the 1960s. This decline resulted in Argentina's failure to acquire high-quality enforcement institutions and to secure property rights. Hyperinflation in the 1970s and 1990s further reduced CIM's ability to capture contract compliance and additionally impeded the process of economic growth.

A slightly different view has been proposed by Spiller and Tommasi (2003), who argue that the seeds of decline might be rooted in the setup of political institutions. In particular, the political institutions in Argentina have changed profoundly since 1947, which has exacerbated an excessively volatile economic policy and led to weak economic growth. 
Slow to mediocre economic growth in twentieth century, Argentina has been attributed to weak capital accumulation, which has generally been associated with poor-quality institutions and distortionary economic policies (Taylor 1992, 1998a, b).

More parsimonious evidence on the seeds of slow Argentine economic growth and subsequent decline has been highlighted by Kydland and Zarazaga (2002). Employing a neoclassical growth model to account for Argentina's economic depression during the lost decade of the 1980s, they found evidence suggesting that the bulk of the variation in economic growth was triggered by levels of capital and labor intensity that proved costly in terms of lost total factor productivity growth.

Several theories have been proposed to explain the subsequent inability of Argentina to catch up with the United States, Canada, and Australia in economic growth. These explanations generally emphasize (a) a definitive end to frontier expansion in the Pampas, with an absence of meaningful alternatives (Di Tella and Zymelman 1967); (b) a different set of political traditions, linked to the origins of immigrants (Platt and Di Tella 1985); (c) an unrestrictive immigration policy that failed to encourage labor scarcity and resulted in low productivity growth (Díaz Alejandro 1985); and (d) a high demographic dependency rate and associated low rate of national saving (Taylor 1992; Taylor and Williamson 1997). A different strand of literature emphasizes (a) the pivotal importance of institutional arrangements and the persistent effects of institutions inherited from Spanish colonialism (Cortés Conde 1998a, b; Gerchunoff and Fajgelbaum 2006); (b) the unstable and often inflexible government (Duncan and Fogarty 1984); (c) a peculiar land allocation scheme favoring a small number of large landowners compared with a large number of small landowners in Canada and the United States (Ferns 1969; Gallo 1983; Solberg 1987; Adelman 1994; Sánchez-Alonso 2000; Fukuyama 2014); (d) widespread tenant agriculture and the lack of agricultural knowledge amid a scarcity of capital goods (Gallo 1993); (e) the erosion of the rule of law since the 1930s, caused by the undermining of the independence of the Supreme Court (Spiller and Tommasi 2003; Colomer 2004; Alston and Gallo 2010); and (f) a distortionary trade and exchange rate policy that pushed up the relative prices of capital goods, lowered capital intensity, and relocated labor from manufacturing to services, possibly leading to Argentina's premature deindustrialization (Rodrik 2016).

Is Argentina's inability to catch up with Western Europe and the United States rooted in its institutional framework? Argentina's institutional development differed fundamentally from that of the United States, Canada, and Australia. The 1853 Constitution enshrined universal male suffrage. From 1912, it was enforced through the Sáenz Peña Law (Crawley 1984; Pucciarelli 1986; Halperín Donghi 1991; Yablón 2003), which made Argentina the first country in Latin America to introduce a universal, secret, and compulsory male suffrage through the creation of an electoral list of voters (padrón electoral). Following the period between World War I and the Great Depression, Argentina began to transition toward democracy and an independent judiciary with a genuine rule of law. Unlike Western Europe and the Western offshoots (Canada, United States, Australia, New Zealand), it never finished the transition. The 1930 military coup in Argentina set the precedent for the unstable institutional development that has prevailed ever since. Under the leadership of José Félix Uriburu, the military overthrew the democratically elected government of Hipólito Yrigoyen, whose party, the Radical Civil Union (Unión Civila Radical, or UCR), formed the 
backbone of middle-class voters and urban professionals. The new military regime established a de facto fascist government with an illegal repressive state apparatus and the creation of special units of the police to systematically harass the regime's political opponents (Schilizzi Moreno 1973; Sanguinetti 1988; Peralta-Ramos 1992; Halperín Donghi 2004).

\section{The framework}

Assume that the world consists of a finite set of countries $j=1,2, \ldots J$. Suppose that $j$-th country has an aggregate Cobb-Douglas production function of the following form:

$$
y_{j t}=K_{j t}^{\alpha} \cdot H_{j t}^{\beta} \cdot\left(A_{j t} L_{j t}\right)^{1-\alpha-\beta},
$$

where $y$ denotes the final good, $K$ denotes the physical capital stock, $H$ denotes the human capital stock, $A$ is the level of technology and $L$ denotes labor supply. The key parameters of interest are $\alpha$ and $\beta$, which represent the rate of return on physical and human capital stock. When $\beta=0$, Cobb-Douglas production function in Eq. (1) nests the basic Solow model without human capital. We assume that the production function is twice continuously differentiable with positive but diminishing marginal products and constant returns to scale, which implies that:

$$
\begin{aligned}
& F_{K}(K, H, A L) \equiv \frac{\partial F}{\partial K}>0 \quad F_{K K}(K, H, A L) \equiv \frac{\partial^{2} F}{\partial K^{2}}<0 \\
& F_{L}(K, H, A L) \equiv \frac{\partial F}{\partial L}>0 \quad F_{L L}(K, H, A L) \equiv \frac{\partial^{2} F}{\partial L^{2}}<0 \\
& F_{H}(K, H, A L) \equiv \frac{\partial F}{\partial H}>0 \quad F_{H H}(K, H, A L) \equiv \frac{\partial^{2} F}{\partial H^{2}}<0
\end{aligned}
$$

We also assume that the production function satisfies the Inada conditions and provides for the existence of the inner equilibria:

$$
\begin{array}{ll}
\lim _{K \rightarrow 0} \frac{\partial F}{\partial K}\left(K_{t}, H_{t}, A_{t} L_{t}\right)=\infty & \lim _{K \rightarrow \infty} \frac{\partial F}{\partial K}\left(K_{t}, H_{t}, A_{t} L_{t}\right)=0 \\
\lim _{L \rightarrow 0} \frac{\partial F}{\partial L}\left(K_{t}, H_{t}, A_{t} L_{t}\right)=\infty & \lim _{L \rightarrow \infty} \frac{\partial F}{\partial L}\left(K_{t}, H_{t}, A_{t} L_{t}\right)=0 \\
\lim _{H \rightarrow 0} \frac{\partial F}{\partial H}\left(K_{t}, H_{t}, A_{t} L_{t}\right)=\infty & \lim _{H \rightarrow \infty} \frac{\partial F}{\partial H}\left(K_{t}, H_{t}, A_{t} L_{t}\right)=0 .
\end{array}
$$

In this particular setup, countries differ in the physical and human capital savings rates, $s_{k}$ and $s_{h}$, population growth rates $\Delta L / L_{t}=n$, and the growth rates of technology $\Delta A_{t} / A_{t}=g_{j}$, and in the initial level of technology. Instead of the aggregate capital stock, we are primarily interested in the capital-labor ratios since the assumed technology takes the Harrod-neutral labor-augmented form, $A L$. For $j$-th country, capital-labor ratios are defined as follows:

$$
\left(\frac{k}{l}\right)_{j}=\frac{K_{j}}{A_{j} L_{j}}
$$




$$
\left(\frac{h}{l}\right)_{j}=\frac{H_{j}}{A_{j} L_{j}}
$$

The focus of the aggregate production function is the steady state defined by capital labor ratios. By assuming depreciation rates, $\delta_{k}$ and $\delta_{h}$, and accumulated savings rates, $s_{k}$ and $s_{h}$, the steady-state equilibrium for $j$-th country is as follows:

$$
\begin{aligned}
& k_{j}^{*}=\left(\left(\frac{s_{k, j}}{n_{j}+g_{j}+\delta_{k}}\right)^{1-\beta}\left(\frac{s_{h, j}}{n_{j}+g_{j}+\delta_{h}}\right)^{\beta}\right)^{\frac{1}{1-\alpha-\beta}} \\
& h_{j}^{*}=\left(\left(\frac{s_{k, j}}{n_{j}+g_{j}+\delta_{k}}\right)^{\alpha}\left(\frac{s_{h, j}}{n_{j}+g_{j}+\delta_{h}}\right)^{1-\alpha}\right)^{\frac{1}{1-\alpha-\beta}}
\end{aligned}
$$

Using steady-state equilibria in Eqs. (4) and (5) together with the capital-labor ratios in Eqs. (2) and (3), per capita output in the neighborhood of the balanced growth path is as follows:

$$
y_{j t}^{*}=\frac{y_{t}}{l_{t}}=A_{j t}\left(\frac{s_{k, j}}{n_{j}+g_{j}+\delta_{k}}\right)^{\frac{\alpha}{1-\alpha-\beta}},
$$

where, following Mankiw et al. (1992), we assume that countries are different in technology level, leading to different values of initial A, but they share the same common technology growth rate, $A_{j t}=\bar{A}_{j} e^{g_{t}}$. Notice that if $g$ is not equal across countries, per capita income will diverge. Using the balanced growth path of per capita output and assuming Mankiw et al. (1992) technology growth dynamics, we obtain the following balanced growth path of income for country $j=1,2, \ldots J$ :

$$
\begin{aligned}
\ln y_{j t}^{*}= & \left\{\ln A_{j}+g_{t}\right\}+\left(\frac{\alpha}{1-\alpha-\beta}\right) \cdot \ln \left(\frac{s_{k}}{n_{j}+g+\delta_{k}}\right) \\
& +\left(\frac{\beta}{1-\alpha-\beta}\right) \cdot \ln \left(\frac{s_{h}}{n_{j}+g+\delta_{h}}\right)+\varepsilon_{t},
\end{aligned}
$$

where $\varepsilon$ denotes the stochastic disturbances capturing the random error term. One of the major challenges in estimating the balanced growth Eq. (7) is that the level of technology is unobserved to the econometrician, and is, thus, absorbed by the random error term. It is also correlated with the capital stock or capital accumulation, which implies that estimating Eq. (7), invokes standard omitted variable bias. Even though one might assume that the level of technology is orthogonal to random error term, $\bar{A}_{j}=\varepsilon_{j} A$ and $E(\varepsilon \mid \mathbf{X})=0$, such assumption has been questioned extensively. Since technology differences are hardly orthogonal, the omitted variable bias and the potential reverse causation between capital stock and growth renders the baseline OLS coefficients in Eq. (7) biased upward. Our partial remedy is to add the vector of control variables to the standard augmented Solow growth equation and the full set of technology shocks that are common to all countries but may differ with respect to the magnitude. Although imperfect, such 
an approach can partially alleviate the omitted variable bias and allow us to estimate the structural parameters consistently.

\section{Long-run development under counterfactual de Jure and de Facto institutional design: an empirical model}

This section presents an empirical model of Argentina's long-run development under counterfactual institutional design using a synthetic control estimator to tackle the long-run effects of institutional breakdowns.

\subsection{Long-run development with de Jure and de Facto political institutions}

The perplexing political history of Argentina and its rampant institutional instability invoke two fundamental dilemmas (Acemoglu et al. 2003). First, what would have happened to Argentina's long-run economic development had it managed to enshrine a set of de jure and de facto political institutions comparable to those of the United States in its constitution and had such an institutional framework actually been enforced? In the absence of institutional breakdowns, would Argentina have remained a rich country? Would its path of economic growth and development have been characterized by a similar slowdown had it established and maintained US-style de jure and de facto political institutions such as competitive polities, an independent Supreme Court, and open access to collective action for the broad cross section of society rather than only for the privileged few? Second, how would Argentina's path of long-run development have changed if it had established USstyle de jure and de facto political institutions at various junctures in the late nineteenth and early twentieth centuries, when it took an unfortunate turn toward institutional breakdowns rather than developing a genuine system of checks and balances?

The aim here is to build a counterfactual scenario of institutional breakdowns, to construct the path of long-run development in the absence of such breakdowns, and to estimate consistently this absence's contribution to long-run development. The absence of breakdowns is simply characterized by the alternative set of de jure and de facto political institutions put in place instead of the existing ones, drawing on Argentina's unique path of departure from a rich country to an underdeveloped one.

For a nonrandom sample of $j=1,2, \ldots J$ countries across $t=1,2, \ldots T$ years, the basic fixed effects relationship that takes place is:

$$
\begin{aligned}
\ln y_{j, t}= & \Omega+\sum_{j=1}^{J} \mu_{j} \cdot 1[j \rightarrow\{0,1\}]+\sum_{t=1}^{T} \phi_{t} \cdot 1[t \rightarrow\{0,1\}] \\
& +\hat{\theta}_{1} \cdot \mathrm{I}_{j, t}^{\text {De Jure }}+\hat{\theta}_{2} \cdot \mathrm{I}_{j, t}^{\text {De Facto }}+\mathbf{X}_{j, t}^{\prime} \beta+\varepsilon_{j, t},
\end{aligned}
$$

where $y$ is the real per capita gross domestic product (GDP) for country $j$ at time $t, \Omega$ is a constant term, the set of country-varying coefficients $\mu_{j}$ captures the set of country fixed effects unobserved by the econometrician, $\phi_{t}$ is the set of technology shocks common to all countries, and [.] is the Iverson bracket in the set of indicator functions, with the vector of country-level and time-level indicator functions capturing the unobserved effects across countries and over time. The key coefficients of interest are $\hat{\theta}_{1}$ and $\hat{\theta}_{2}$, which denote, respectively, the contributions of de jure and de facto political institutions 
to long-run development. The vector $\mathbf{X}$ captures the set of covariates that systemically influence the paths of long-run development, such as culture, geography, and legal history, to prevent the effects of de jure and de facto institutions from being contaminated by omitted variable bias. The stochastic disturbances that contain the unobservables are captured by $\varepsilon$.

The key challenge posed by the empirical setup hinges on the reliability of the standard errors, which critically affect the consistency of the estimated responses of long-run development to the changes in the de jure and de facto political institutions. A major threat to the proposed empirical design is related to the possibility of multiple serially correlated stochastic disturbances both across and within countries. The serial correlation in the unobservable component could lead to massively underestimated standard errors, which would imply that the underlying null hypothesis on the effects of de jure and de facto political institutions was over-rejected because of the underestimated standard errors, which would invoke the Kloek-Moulton bias (Kloek 1981; Moulton 1986, 1990). In the absence of mitigation of the multiple sources of serially correlated stochastic disturbances, the serial correlation in unobservables can persist even when the unobserved country-fixed effects and time-fixed effects are controlled for. Valid standard errors and the underlying inference regarding the true contribution of de jure and de facto political institutions critically require overcoming the one-way clustering of standard errors using a multiway clustering scheme that allows the parameter estimates to be robust against within-country and between-country serially correlated stochastic disturbances (Bertrand et al. 2004; Kézdi 2004).

To mitigate the distribution of serially correlated stochastic disturbances, the empirical setup uses a non-nested multiway clustering estimator from Cameron et al. (2011). The standard errors are simultaneously clustered at country and year levels using the twoway error component model with independent and identically distributed (i.i.d.) residuals (Moulton 1986; Davis 2002; Pepper 2002) instead of one-way clustering (White 1980, 1984; Pfeffermann and Nathan 1981; Liang and Zeger 1986; Arellano 1987; Hansen 2007; Wooldridge 2003; Cameron and Trivedi 2005), which may lead to the over-rejection of the null hypotheses, rendering the standard errors and parameter inference unreliable.

\subsection{Constructing the counterfactual scenario}

I construct the counterfactual distribution and set out to examine the alternative path of long-run development in the absence of institutional breakdown by using a synthetic control setup whose purpose is not to tackle the direct effects of policy changes. Suppose $J+1$ countries are observed over $t=1,2, \ldots, T$ periods, with Argentina being the country affected by the institutional breakdowns and with other countries $\{2, \ldots J+1\}$ being unaffected by such breakdowns. Suppose the institutional breakdown (which affects only Argentina and leaves the other $J$ countries unaffected) occurs at period $T_{0}+1,1<T_{0}+1<T$. Let $\ln y_{i, t}^{N}$ denote the per capita GDP for country $i$ at time $t$ in the absence of the breakdown, and let $\ln y_{i, t}^{I}$ denote the per capita GDP observed for country $i$ at time $t$ if the country were exposed to the breakdown. Furthermore, assume that the breakdown had no effect on the outcome before it took place, $Y_{i, t}^{N}=Y_{i, t}^{I}$ for all $i$, and $t<T_{0}+1$. The aim is to estimate the effect of institutional breakdowns over time 
for the treated unit. If $\alpha_{1}=\left(\alpha_{1}, \alpha_{T_{0}+1}, \ldots, \alpha_{1, T}\right)$ denotes the vector of effects from the treated sample, for $t>T_{0}$, the breakdown effect can be decomposed into:

$$
\alpha_{1, t}=\ln y_{1, t}^{I}-\ln y_{1, t}^{N}=\ln y_{1, t}-\ln y_{1, t}^{N},
$$

where $\ln y_{1, t}$ denotes the observed per capita GDP and $\ln y_{1, t}^{N}$ is the counterfactual per capita GDP in the absence of institutional breakdowns. It is assumed that $\ln y_{1, t}^{N}$ follows a latent factor model for all $i=1,2, \ldots, N$ of the following form:

$$
\ln y_{1, t}^{N}=\delta_{t}+\theta_{t} \mathbf{X}_{i, t}^{\prime}+\lambda_{t} \mu_{t}+\varepsilon_{i, t}
$$

where $\delta_{t}$ is an unobserved factor common across all countries, $\mathbf{X}_{i, t} \in \mathbb{R}^{r}$ is a vector of observed covariates unaffected by the breakdown, $\theta_{t} \in \mathbb{R}^{r}$ is a vector of parameters, $\lambda_{t} \in \mathbb{R}^{r}$ is a vector of common unobserved factors, and $\mu_{i} \in \mathbb{R}^{r}$ is a vector of unknown factor loadings. Parametrically, $\varepsilon_{i, t}$ denotes the i.i.d. shocks. The latent factor model allows for heterogeneous responses to multiple unobserved factors and, at the same time, embeds time trends into the underlying long-run development model. However, it implicitly assumes that the factor count is fixed over time and therefore exhibits no structural breaks. Taking the latent factor model, I construct the synthetic counterfactual trajectory by reweighing the control group so that a "synthetic" Argentina matches $\mathbf{X}_{i, t}$ and some of its pre-breakdown $\ln y_{i, t}$. Hence, $\mu_{i}$ is matched by default, allowing for heterogeneous responses to the multiple unobserved factors.

Let $W=\left(w_{2}, \ldots, w_{J+1}\right)$ be a vector of weights with $w_{j} \geq 0 \forall j$, where each value of $W$ represents a potential synthetic control. For a given $W$, the per capita GDP for a synthetic control at time $t$ is

$$
\begin{aligned}
\ln y_{W, t}= & \sum_{j=2}^{J+1} w_{j} \ln y_{j, t}=\delta_{t}+\theta_{t}\left(\sum_{j=2}^{J+1} w_{j} X_{j}\right) \\
& +\lambda\left(\sum_{j=2}^{J+1} w_{j} \mu_{j}\right)+\left(\sum_{j=2}^{J+1} w_{j} \varepsilon_{j, t}\right),
\end{aligned}
$$

where it is assumed that $\exists W^{*}$ is such that the synthetic control is set to match the treated unit in the pre-breakdown period so that $\sum_{j=2}^{J+1} w_{j}^{*} Y_{j, t}=Y_{1, t} \quad \forall t \in\left\{1, \ldots, T_{0}\right\}$ and $\sum_{j=2}^{J+1} w_{j}^{*} X_{j}=X_{1}{ }^{7}$ If the conditions are met, the synthetic control associated with $W^{*}$ replicates the missing counterfactual. The baseline synthetic control model (Abadie et al. 2010) for a single treated unit is adopted. Hence, an approximately unbiased estimator of $\alpha_{1, t}$ is then given by

$$
\hat{\alpha}_{1, t}=\ln y_{1, t}-\sum_{j=2}^{J+1} w_{j}^{*} \ln Y_{j, t}=\ln Y_{1, t}-\ln Y_{W *, t}
$$

\footnotetext{
${ }_{7}$ It is furthermore assumed that $\sum_{t=1}^{T_{0}} \lambda_{t}^{\prime} \lambda_{t}$ is non-singular. Then, for all $t>T_{0}, E\left[\ln y_{j, t}^{N}-\sum_{j=2}^{++1} w_{j}^{*} \ln y_{j, t}\right] \rightarrow 0$ as $T_{0} \rightarrow \infty$
or if $T_{0}$ is large relative to the postshock period. 
where a nested weight matrix is used to minimize the root-mean-square prediction error and compute a reasonably unbiased synthetic match of the treated unit. Compared with difference-in-differences analysis, the synthetic control method imposes less restrictive functional assumptions on the estimation process. Under a data-driven approach to the counterfactual estimation, $W^{*}$ forces the data to exhibit parallel trends in the pre-breakdown period, because the validity of the synthetic estimates crucially hinges on the parallel trend assumption.

\section{Data}

This section briefly discusses sample selection, outcome variables, data used to construct the indices of economic and institutional development, and coding of institutional breakdowns.

\subsection{Outcomes and samples}

The sample comprises 28 countries for the period 1850-2012. The measure of longrun development, as well as the outcome variable, is real per capita GDP at 1990 constant prices, denoted in Geary-Khamis international dollars from Bolt and Van Zanden (2014) following earlier work by Maddison (2007a, b). Because the focus is on Argentina, the data on per capita GDP stretch back to 1850 and are based on earlier work by economic historians Bértola and Ocampo (2012) and Prados de la Escosura and Sanz-Villarroya (2009). The annual data are used to overcome the compression of long historical periods (Austin 2008) and the subsequent bias in the direction of the underlying effects of de jure and de facto political institutions. For the pre-1870 period, a simple linear interpolation is used between 1850 and 1870 to yield an overall annual variation in per capita GDP over time. Figure 1a, plots the path of Argentina's per capita GDP against that of the United States for the period 1850-2012. At face value, the evidence clearly suggests that until 1900 Argentina managed to parallel the US per capita output level. Following a relatively smaller output decline during the Great Depression in the early 1930s, Argentina embarked on a path of comparatively greater output stagnation relative to the United States and a markedly slower rate of economic growth, especially in the years following the 1930 military coup. Figure 1b, maps the long-run development of Argentina compared with other countries.

\subsection{De Jure and de Facto political institutions: a factor analysis}

The definition of institutions that is used in this paper relies on North (1990), whereas the delineation between de jure and de facto political institutions is based on Feld and Voigt (2003), Pande and Udry (2005), Acemoglu and Robinson (2006a), Robinson (2013), Shirley (2013), Voigt (2013), Földvári (2016), and Spruk (2016). In their broadest form, the de jure political institutions capture the set of rules allocating political power through a formal institutional framework such as electoral law and the constitution. The de facto political institutions denote the ability to engage in various forms of collective action and contest the political power of the elites. The distinction between de jure and de facto political institutions is crucial, because the balance of the de jure and de facto political power of the elites tends to shape the structure and equilibrium of economic institutions and, together with procedural details, bears directly on economic 


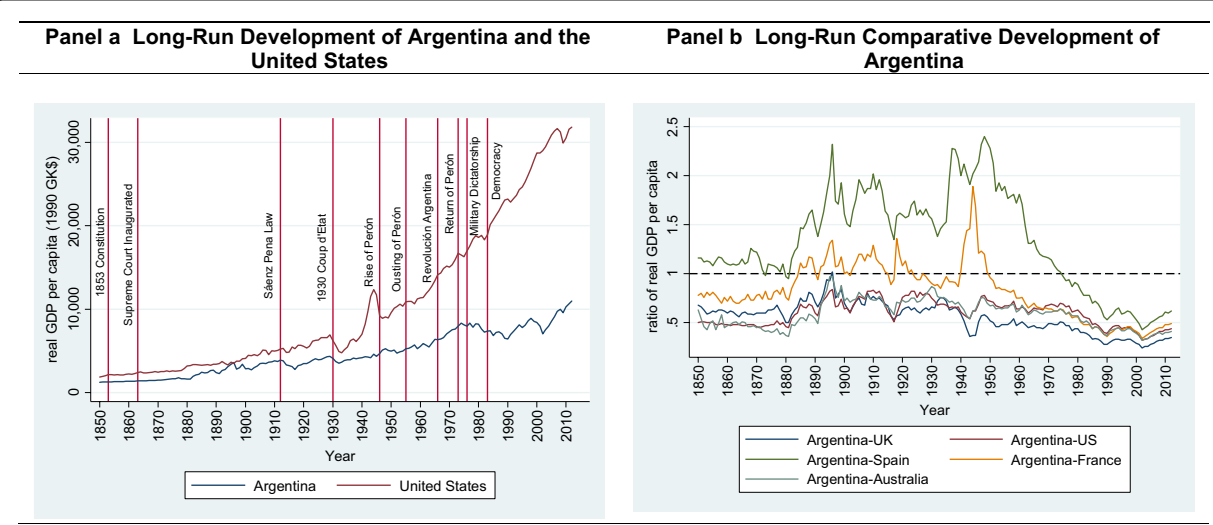

Fig. 1 Argentina's comparative development, 1850-2012 (Source: Bolt and van Zanden (2014))

performance (Summerhill 2000). Acemoglu and Robinson (2006a) suggest that both sets of political institutions exert a strong form of temporal persistence. "Put differently," they write, "when the elites who monopolize the de jure political power lose this privilege, they may still disproportionately influence in politics by increasing the intensity of their collective action (e.g., in the form of greater lobbying, bribery, or downright intimidation and brute force), and thus ensure the continuation of the previous set of economic institutions" (Acemoglu and Robinson 2006a, 326). ${ }^{8}$ In contrast, McCloskey $(2016,69)$ believes the various layers of institutions coincide with a "great deal" of social ethics, which is needed to support bourgeois virtues as the precursor for sustained and broadbased institutional development. ${ }^{9}$

In this paper, the data on the de jure political institutions are from the Polity IV Annual Dataset (Marshall et al. 2013), which contains the quantitative indicators of the formal regime characteristics as a proxy for the distribution of de jure political power. The underlying polity index comprises six subindicators that capture the distribution of de jure political power: (a) competitiveness of executive recruitment, (b) openness of executive recruitment, (c) executive constraints, (d) de jure competitiveness of political participation, (e) formal regulation of political participation, and (f) competitiveness of

\footnotetext{
${ }^{8}$ Acemoglu and Robinson (2006a, 326) illustrate the persistence of de jure and de facto political power, drawing on the Southern Equilibrium in the aftermath of the US Civil War: "One of the best examples of the persistence of economic institutions as a consequence of the persistence of de facto power comes from the southern United States. In the antebellum period, the South was particularly poor...; had an urbanization rate of 9 percent as opposed to 30 percent in the Northeast; had relatively few railroads or canals; and was technologically stagnant. The economy was based on slavery and labor-intensive cotton production, and in many states it was illegal to teach slaves how to read and write. After the Civil War, with the abolition of slavery and enfranchisement of the freed slaves, one might have anticipated a dramatic change in economic institutions. Instead, what emerged was a labor-intensive, low-wage, low-education, and repressive economy that in many ways looked remarkably like that of the antebellum South. Slavery was gone, but in its place were the Ku Klux Klan and Jim Crow. Why did the Southern Equilibrium persist? Despite losing the Civil War, antebellum elites managed to sustain their political control of the South, particularly after the reconstruction ended in $1877 . .$. They successfully blocked the economic reforms that might have undermined this power... They also derailed political reforms they opposed, and freed slaves were quickly disenfranchised through the use of literacy tests and poll taxes. Consequently, although slavery was abolished, Southern elites still possessed considerable de facto power through their control over economic resources, their greater education, and their relative ability to engage in collective action.".

9 McCloskey $(2016,69)$ further illustrates the necessity of social ethics for institutional development: "I don't think institutions work without a great deal of social ethics-think of the constitutions of the USSR or the Russian Federation think of the laws on rape being the same in Uganda and in the United Kingdom, with very different results. Abraham Lincoln declared in the first of the Lincoln-Douglas debates of 1858, 'With public sentiment, nothing can fail; without it nothing can succeed. Consequently, he who molds public sentiment goes deeper than he who enacts statues or pronounces decisions. He makes statutes and decisions possible or impossible to be executed"' (emphasis in original).
} 
political participation (Treier and Jackman 2008; Marshall et al. 2013). The data on the de facto political institutions are from Vanhanen's index of democracy in the Polyarchy Dataset (Vanhanen 2000, 2003) for the period 1850-2012 and are used to construct the comparable indices of de facto political institutions in the long-term perspective. In its broadest form, the index of democracy captures the ability of nonelites to engage in various forms of collective action and to contest the political power of the elites in free and fair regular elections. The index of democracy comprises two underlying subindices: (a) the index of political competition and (b) the index of political participation. First, the index of political competition is constructed on the basis of the percentage share of votes cast for smaller political parties and independents in parliamentary elections or their share of the number of seats in the parliament. The index is constructed by simply subtracting the largest party's vote share from 100 percent. Second, the index of political participation is composed of the percentage of the adult population that voted in the elections, which broadly reflects the ability of nonelites to contest the political power of elites and to engage in the process of collective action.

The use of voting rates as an indicator of de facto political institutions has been the subject of scholarly criticism. Many avenues besides voting rates exist for influencing collective action. In this respect, a political competition index might overtly neglect proportional representation versus a first-past-the-post system, because the index yields higher values for systems having a greater number of small parties. Hence, countries such as the United Kingdom and the United States automatically score much lower on a de facto institutional metric than do countries with proportional representation, even though they are stable democracies that recognize the rule of law, possibly to a much greater degree than many countries with proportional representation. Despite such easily acknowledged limitations, voting rates provide an easily trackable indicator of de facto political rights that can be compared across countries and over time. Although a measure of informal norms would be more appropriate for such purposes, no such indices or data currently exist for the greater part of the time series being studied in this paper.

My aim is to construct consistent and both internally and externally valid indices of de jure and de facto political institutions in which the maximum temporal and spatial variance is extracted from each underlying component (Bollen 1990; Pemstein et al. 2010). To this end, I have used the factor analytic (FA) approach to construct the de jure and de facto indices of political institutions. Using the FA approach, I have constructed two major latent indices of political institutions from the underlying Polity IV and Vanhanen ID components. The two indices are constructed from eight different subindicators. The rotated components indicate that the first dimension correlates strongly with four Polity IV indicators, which reflects the structure of de jure political institutions. The second major dimension correlates strongly with political competition, executive constraints, and political participation, which is characteristic of de facto political institutions. Cronbach's alpha (Cronbach 1951) indicates that both latent indices exhibit a high degree of internal consistency. For the latent index of de jure political institutions, $\alpha=0.81$, and for the latent index of de facto political institutions, $\alpha=0.70$, which indicates very little structural inconsistency and measurement error. In Fig. 2, the path of de jure and de facto institutional development is presented for Argentina and the United States. The 


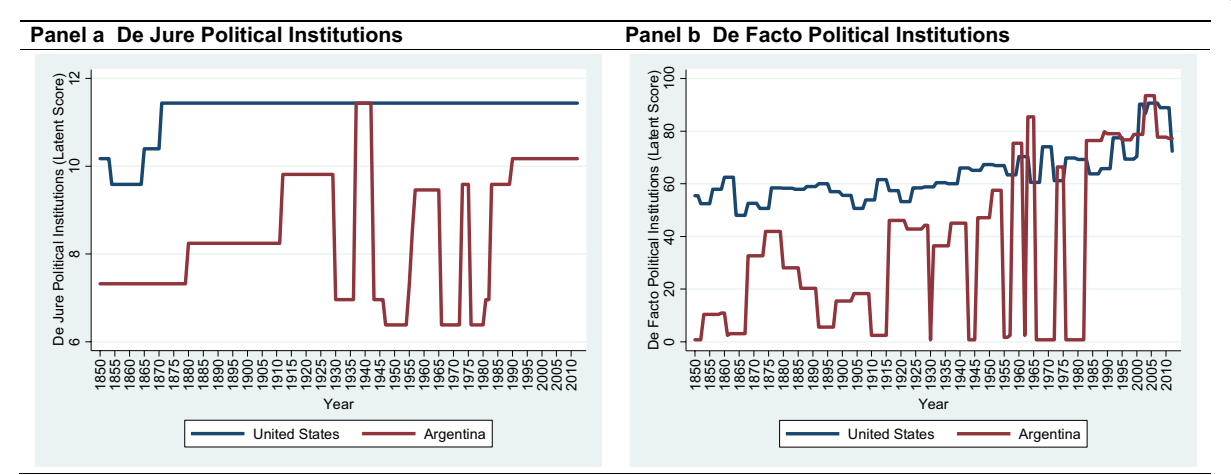

Fig. 2 De Jure and de Facto Institutional Development of Argentina and the United States, 1850-2012 (Source: Marshall et al. (2013))

figure clearly shows that Argentina's path of de jure and de facto institutional development is characterized by persistent instability, reversals, and breakdowns.

\subsection{Institutional breakdowns}

Argentina's institutional breakdowns are gauged by abrupt shifts in both indices of de jure and de facto political institutions discussed earlier. To examine the contribution of institutional breakdowns to the country's long-run development, one must focus on the major turning points in Argentina's institutional history in the aftermath of the 1853 Constitution that eventually led to the series of institutional breakdowns. Because the goal is to construct the counterfactual scenario of long-run development without institutional breakdowns, the proposed empirical strategy does not facilitate the measurement of breakdowns from a substantive point of view. The period in which the breakdown of checks and balances and the democratic institutions evolved is used as a starting point to build a counterfactual scenario. The counterfactual scenario can perhaps best be summarized in a single dilemma: what would have happened to Argentina's long-run development had its de jure and de facto political institutions, such as competitive polity, access to collective action for nonelites, and an independent Supreme Court, followed developments in parallel countries that did not experience breakdowns, starting with the 1930 military coup? The counterfactual series on de jure and de facto political institutions are constructed by building eight specific counterfactual scenarios that meet the de jure and de facto institutional design. Specifically, eight different dates are considered in the counterfactual scenario: (a) the 1930 coup, (b) Perón's rise to power (1946), (c) the Revolución Libertadora (Liberating Revolution) that resulted in the ousting of Perón (1955), (d) the beginning of a period of fragile UCR administrations and political instability (1958), (e) the Revolución Argentina (Argentine Revolution) and the shift to an authoritarian and bureaucratic state (1966), (f) the second Perón era (1972), (g) the onset of military dictatorship (1976), and (h) the formal transition to democracy (1983). The 1912 Sáenz Peña Law is used as a robustness check. Using these dates allows the model to project Argentina's long-run development in the absence of institutional breakdowns occurring within these dates-that is, if, instead, Argentina had followed the de jure and de facto institutional development in plausibly similar countries. Table 1 gives a summary of the institutional breakdowns used to construct the counterfactual scenario, 
along with Argentina's mean per capita GDP level at the breakdown period in question, the growth rate, and the standard deviation.

\subsection{Covariates and descriptive statistics}

A great deal of the variation in Argentina's long-run development is not driven exclusively by the de jure and de facto institutional setup, and not everyone would agree that such institutions played the pivotal role in the country's long-run development process. The importance of physical geography and factor endowments for long-run development has been confirmed empirically by several researchers, including Engerman and Sokoloff (1997); Bloom and Sachs (1998); (Gallup et al. 1999); Sokoloff and Engerman (2000); Sachs and Malaney (2002); and (Dell et al. 2012). Some scholars are convinced that Argentina's legal history and experience with colonization critically shaped the country's long-run development path (La Porta et al. 2008; Acemoglu et al. 2001, 2002; Feyrer and Sacerdote 2009; Bruhn and Gallego 2012). Others are convinced that culture played the decisive role and held long-lasting implications for growth and development (Guiso et al. 2006; Becker and Woessmann 2009; Algan and Cahuc 2010; Tabellini 2010; Gorodnichenko and Roland 2011; Ashraf and Galor 2013). Still other scholars believe that precolonial biological and genetic setup explain contrasting development paths taken by Argentina (Spolaore and Wacziarg 2009, 2013; Nunn and Qian 2011; Cook 2014).

In the present study of 28 countries, the ability to contain the omitted variable bias by controlling for the set of observable factors is constrained by the limited data available for the temporal period. The covariates used to address the omitted variable bias are assigned to three major groupings: (a) geography and factor endowments, (b) legal history, (c) culture, and (d) production factors. The data on geography are from Nunn and Puga (2012). Nine distinctive physical geography covariates are included in the set of conditioning variables: (a) latitude, (b) longitude, (c) terrain ruggedness, (d) soil quality, (e) fraction of the land area covered by desert, (f) fraction of the land area in the tropical zone, (g) percentage of the land area within $100 \mathrm{~km}$ of the coast, (h) an indicator variable measuring whether the country is landlocked or not, and (i) precipitation levels. Latitude and longitude variables are expressed in standard decimal degrees for the geographic centroid of the country. Terrain ruggedness captures the topographic heterogeneity and is based on the US Geological Survey's Global 30 Arc-Second Elevation Dataset (GTOPO30). GTOPO30 projects horizontal grid spacing at 30 arc-second intervals across Earth's entire surface using a simple geographic projection between two adjacent grid points. Soil quality is captured by the fraction of fertile soil according to the Digital Soil Map of the World created by the Food and Agriculture Organization of the United Nations and the United Nations Educational, Scientific, and Cultural Organization. The distance from coast covariate is calculated as the simple unweighted fraction of the area within a 100-km radius of the closest ice-free coast in equirectangular projection, with standard parallels determined at 30 degrees on the basis of sea and sea ice area features, excluding inland water surfaces. Rainfall precipitation is denoted as the depth of total annual rainfall expressed in millimeters.

The data on legal history are from (La Porta et al. 2008) and capture the legal origin of a given country across four major categories: (a) English common law, (b) French civil 
Table 1 Argentina's institutional breakdowns. Source: Based on data from Bolt and van Zanden (2014)

\begin{tabular}{|c|c|c|c|c|c|}
\hline \multirow[t]{2}{*}{ Breakdown } & \multirow{2}{*}{$\begin{array}{l}\text { Characteristics } \\
\text { of breakdown }\end{array}$} & \multirow[t]{2}{*}{ Period } & \multicolumn{3}{|c|}{ GDP per capita } \\
\hline & & & Level (\$) & Growth rate (\%) & $\begin{array}{l}\text { Standard } \\
\text { deviation }\end{array}$ \\
\hline Military coup & $\begin{array}{l}\text { Electoral fraud, legislative } \\
\text { malapportionment }\end{array}$ & 1930-1943 & 3994 & -0.3 & 4.5 \\
\hline Rise of Perón & $\begin{array}{l}\text { Prosecution, repression, } \\
\text { and torture of political } \\
\text { opponents; widespread } \\
\text { government favoritism; } \\
\text { end of judicial independ- } \\
\text { ence; forced resigna- } \\
\text { tion of Supreme Court } \\
\text { justices; nullification of } \\
\text { constitution }\end{array}$ & 1946-1955 & 4992 & 1.8 & 4.8 \\
\hline Revolución Libertadora & $\begin{array}{l}\text { Ban of political parties, } \\
\text { civilian and military } \\
\text { power seizure, govern- } \\
\text { ment favoritism, forced } \\
\text { resignation of Supreme } \\
\text { Court justices }\end{array}$ & 1955-1958 & 5420 & 3.3 & 1.7 \\
\hline $\begin{array}{l}\text { Fragile radical (UCR) } \\
\text { administrations }\end{array}$ & $\begin{array}{l}\text { Widespread government } \\
\text { favoritism, use of execu- } \\
\text { tive power to declare } \\
\text { state of economic } \\
\text { emergency, legislative } \\
\text { malapportionment, ban } \\
\text { of political parties, power } \\
\text { seizure by military }\end{array}$ & 1958-1966 & 5790 & 1.6 & 5.8 \\
\hline Revolución Argentina & $\begin{array}{l}\text { Coup, end of university } \\
\text { autonomy, armed guer- } \\
\text { rilla violence, forced } \\
\text { resignation of Supreme } \\
\text { Court justices }\end{array}$ & 1966-1973 & 7095 & 2.7 & 2.2 \\
\hline Second Perón era & $\begin{array}{l}\text { Expropriation of foreign } \\
\text { bond holdings, forced } \\
\text { resignation of Supreme } \\
\text { Court justices, nationali- } \\
\text { zation of banks, prohibi- } \\
\text { tion of foreign media } \\
\text { services, abrogation of } \\
\text { university autonomy }\end{array}$ & 1973-1976 & 8095 & 1.0 & 3.8 \\
\hline Military dictatorship & $\begin{array}{l}\text { Brutal violence against } \\
\text { political opponents, } \\
\text { assassinations in various } \\
\text { parts of civil society, mas- } \\
\text { sive violation of human } \\
\text { rights, political arrests } \\
\text { without trial, torture and } \\
\text { intimidation, politiciza- } \\
\text { tion of armed forces, } \\
\text { forced resignation of } \\
\text { Supreme Court justices }\end{array}$ & 1976-1983 & 7843 & -1.1 & 4.7 \\
\hline
\end{tabular}

law, (c) German civil law, and (d) Scandinavian civil law. Because not a single country in the sample is characterized by socialist law, this particular subgroup is excluded from the full sample. The legal origin is captured by a simple indicator variable, and given its time invariance, the underlying indicators reflect the long-run differences between countries in their rates of economic growth across different streams of legal tradition. The data on 
culture are from Alesina et al. (2003). Because the standard culture covariates do not stretch back in time on a 100-year basis, three distinctive time-invariant covariates are included in the set of conditioning variables: (a) ethnic fractionalization, (b) linguistic fractionalization, and (c) religious fractionalization. Because such measures appear to be highly stable and persistent over time, the relationship with respect to long-run development is apparent. The set of fractionalization covariates captures the cultural differences across countries. The underlying measure of fractionalization is constructed as a simple Hirschman-Herfindahl concentration index by subtracting the shares of ethnic, linguistic, or religious groups from unity. Higher values of the index correspond to greater ethnic, linguistic, and religious homogeneity in the population in space and time. The data on production factors are from Feenstra et al. (2015) We calculate the physical capital stock per worker as a measure of capital accumulation, and use the data on the combined index of average years of education (Barro and Lee 2013) and returns to schooling (Psacharopoulos 1994) as a proxy for human capital investment. Notice that since the production factor variables are available for the post-1950 period only, the analysis with the production factors is restricted to this specific period.

The sample used in the empirical analysis to establish the contribution of de jure and de facto political institutions to long-run development comprises 28 countries for the period 1850-2012 on an annual basis, with 19 covariates in the set of independent variables, which totals 4564 baseline country-year observations. Table 2 reports the underlying descriptive statistics for the full unrestricted sample.

\section{Results}

This section discusses the conditional long-run development effects of de jure and de facto political institutions followed by a discussion of synthetic counterfactual estimates.

\subsection{Baseline results}

In Table 3, the effects of de jure and de facto political institutions on long-run development are presented in depth. The results clearly highlight the fundamental importance of the de jure and de facto political institutions in shaping the paths of long-run development. Columns (1) through (4) display the evidence using the full sample. In column (1), the point estimates suggest that a one-basis-point improvement in the latent index of de jure political institutions is associated with a 2.6 percent increase in per capita income, whereas the same improvement in the de facto institutional index is associated with a 2.2 percent increase in per capita income. The de jure and de facto political institutions account for up to 73 percent of the between-country and within-country differences in per capita income.

In the absence of the covariates, the unconditional estimates of de jure and de facto institutional effects on long-run development are likely to be conflated by omitted variable bias. In column (2), the geography covariates are added to the list of control variables. The evidence indicates that the core effects of de jure and de facto political institutions appear to be highly insensitive to the direct and confounding effects of physical geography on long-run development. The direct contribution of physical geography covariates tends to be weak, although jointly significantly different from zero $(p$ value $=0.000)$. In column $(3)$, the legal history and tradition covariates from 
Table 2 Descriptive statistics

\begin{tabular}{|c|c|c|c|c|c|c|c|}
\hline & \multirow{2}{*}{$\begin{array}{l}\text { Number } \\
\text { of observations }\end{array}$} & \multirow[t]{2}{*}{ Mean } & \multicolumn{3}{|c|}{ Standard deviation } & \multirow[t]{2}{*}{ Minimum } & \multirow[t]{2}{*}{ Maximum } \\
\hline & & & Overall & Between & Within & & \\
\hline \multicolumn{8}{|l|}{ Outcomes } \\
\hline Real GDP per capita (\$) & 4564 & 5234 & 5889 & 2756 & 5230 & 397 & 31,711 \\
\hline \multicolumn{8}{|c|}{ Latent indices of political institutions } \\
\hline De jure & 4564 & 10.22 & 10.58 & 8.63 & 6.32 & 0 & 93.23 \\
\hline De facto & 4564 & 45.51 & 37.34 & 24.38 & 28.65 & -2.39 & 119.13 \\
\hline \multicolumn{8}{|l|}{ Geography covariates } \\
\hline Latitude & 4564 & 30.63 & 26.79 & 27.27 & - & -36.3 & 59.55 \\
\hline Longitude & 4564 & 3.08 & 58.36 & 59.42 & - & -99.10 & 139.83 \\
\hline Terrain ruggedness & 4564 & 1.65 & 1.29 & 1.31 & - & 0.037 & 5.043 \\
\hline Soil quality & 4564 & 39.66 & 17.20 & 17.52 & - & 0.073 & 69.97 \\
\hline Desert (\%) & 4564 & 0.84 & 3.02 & 3.08 & - & 0 & 15.48 \\
\hline Tropical (\%) & 4564 & 14.40 & 32.81 & 33.41 & - & 0 & 99.54 \\
\hline Distance to coast & 4564 & 42.39 & 33.50 & 34.11 & - & 0 & 100 \\
\hline Landlocked & 4564 & 0.10 & 0.309 & 0.314 & - & 0 & 1 \\
\hline Log precipitation & 4564 & 6.87 & 0.52 & 0.53 & - & 5.42 & 8.08 \\
\hline \multicolumn{8}{|l|}{ Legal history covariates } \\
\hline Common law & 4564 & 0.14 & 0.34 & 0.35 & - & 0 & 1 \\
\hline French civil law & 4564 & 0.57 & 0.49 & 0.50 & - & 0 & 1 \\
\hline German civil law & 4564 & 0.17 & 0.38 & 0.39 & - & 0 & 1 \\
\hline Scandinavian civil law & 4564 & 0.10 & 0.30 & 0.31 & - & 0 & 1 \\
\hline \multicolumn{8}{|l|}{ Culture covariates } \\
\hline Ethnic fractionalization & 4564 & 0.30 & 0.22 & 0.22 & - & 0.01 & 0.67 \\
\hline Linguistic fractionalization & 4564 & 0.22 & 0.22 & 0.22 & - & 0.02 & 0.75 \\
\hline Religious fractionalization & 4564 & 0.35 & 0.22 & 0.22 & - & 0 & 0.82 \\
\hline
\end{tabular}

(La Porta et al. 2008) are added to the battery of independent variables. The underlying effects of the de jure and de facto political institutions remain intact and statistically significant at 1 percent. In the absence of controlling for the legal history and tradition, the de jure point estimate is likely to be slightly biased upward, by 23 percent, whereas the directional bias does not seem to affect the de facto point estimate.

In column (4), the culture covariates are added to the set of conditioning variables in the full-model specification, which does not exclude either group of long-run development confounders. The results further highlight the ubiquitous presence of omitted variable bias in the absence of the full-model specification. Adding culture covariates to the set of conditioning variables suggests that culture does make a difference in long-run development but, at the same time, does not seem either to dominate the full effects or to render the de jure and de facto political institutions insignificant in explaining the paths of long-run development. Compared to column (1), the de jure coefficient drops to 0.018 , which is proportional to a 44 percent upward bias in the absence of controlling for the effects of culture, physical geography, and legal history and tradition on long-run development. Conversely, the point estimate on the de facto political institutions remains essentially intact and does not appear to be wholly driven by the set of conditioning variables. Broadly speaking, the evidence clearly suggests that the de jure and de facto political institutions tend to produce one of the 
Table 3 Conditional effects of de Jure and de Facto political institutions on long-run development, 1850-2012

Full sample

(1) (2)

$$
\text { (2) }
$$

(3)

(4)

De jure and de facto political institutions

$\begin{array}{cc}\text { De jure } & 0.026^{* * *} \\ \text { (latent) } & (0.001) \\ \text { De facto } & 0.022^{* * *} \\ \text { (latent) } & (0.001) \\ \text { Geography covariates } \\ \text { Latitude }\end{array}$

Latitude
Longitude
Terrain rug-
gedness
Soil quality

Desert

Tropical

Distance to

coast

Land-

locked

Precipita-

tion

Legal history covariates

English

common

law

French civil

law

German

civil law

Scandina-

vian civil

law

Culture covariates

Ethnic

fraction-

alization

Linguistic

fraction-

alization

Religious

fraction-

alization

Constant
term

Number of 456

$(0.100)$

4564

observa-

tions

Number of 28 countries

Number of 163

years

28

Without Argentina

(5) (6) (7) (8)

(8)

$\begin{array}{rrrr}0.027^{* * *} & 0.026^{* * *} & 0.021^{* * *} & 0.018^{* * *} \\ (0.001) & (0.001) & (0.002) & (0.001) \\ 0.022^{* * *} & 0.022^{* * *} & 0.023^{* * *} & 0.022^{* * *} \\ (0.001) & (0.002) & (0.001) & (0.001)\end{array}$

$$
\begin{array}{ccc}
-0.002 & -0.003^{* * *} & -0.004^{* * *} \\
(0.001) & (0.001) & (0.001) \\
-0.001^{* *} & -0.003^{* * *} & -0.005^{* * *} \\
(0.0008) & (0.0008) & (0.0009) \\
-0.045 & -0.021 & -0.056 \\
(0.049) & (0.039) & (0.045) \\
0.0006 & -0.0006 & -0.001 \\
(0.002) & (0.002) & (0.002) \\
0.008 & -0.006 & -0.027^{* * *} \\
(0.009) & (0.010) & (0.009) \\
0.0002 & 0.001 & 0.003^{* *} \\
(0.001) & (0.001) & (0.001) \\
0.001 & 0.003^{* * *} & 0.003^{* * *} \\
(0.001) & (0.001) & (0.001) \\
0.263 & 0.086 & -0.493^{* *} \\
(0.270) & (0.192) & (0.206) \\
-0.230^{* *} & -0.361^{* * *} & -0.242^{* * *} \\
(0.106) & (0.148) & (0.068)
\end{array}
$$$$
\begin{array}{lll}
(0.106) & (0.148) & (0.068)
\end{array}
$$

$$
-0.381^{* * *}-0.653^{* * *}
$$$$
\text { (0.148) (0.147) }
$$$$
-0.528^{* * *}-0.881^{* * *}
$$$$
\text { (0.131) (0.138) }
$$$$
\text { omitted omitted }
$$$$
-0.567^{* * *}-0.817^{* * *}
$$$$
\text { (0.148) (0.160) }
$$

$$
\begin{array}{ccc}
-0.001 & -0.003^{*} & -0.004^{* * *} \\
(0.002) & (0.001) & (0.001) \\
-0.001^{* *} & -0.003^{* * *} & -0.005^{* * *} \\
(0.0008) & (0.0008) & (0.0009)
\end{array}
$$$$
\begin{array}{lll}
-0.037 & -0.019 & 0.059
\end{array}
$$$$
\begin{array}{lll}
(0.050) & (0.041) \quad(0.048)
\end{array}
$$$$
0.001 \quad-0.0005 \quad 0.001
$$$$
\begin{array}{lll}
(0.002) & (0.003) \quad(0.003)
\end{array}
$$$$
0.014-0.005-0.025^{* * *}
$$$$
\begin{array}{lll}
(0.012) & (0.012) \quad(0.009)
\end{array}
$$$$
0.0008 \quad 0.001 \quad 0.003^{* * *}
$$$$
\begin{array}{lll}
(0.002) & (0.001) & (0.001)
\end{array}
$$$$
0.001 \quad 0.003^{* * *} \quad 0.003^{* *}
$$$$
\begin{array}{lll}
(0.001) \quad(0.001) \quad(0.001)
\end{array}
$$$$
\begin{array}{lll}
0.232 & 0.077 & -0.501^{* *}
\end{array}
$$$$
\begin{array}{lll}
(0.279) & (0.197) & (0.212)
\end{array}
$$$$
-0.215^{*}-0.363^{* * *}-0.239^{* * *}
$$$$
\begin{array}{lll}
(0.118) & (0.101) & (0.082)
\end{array}
$$

$$
\begin{array}{cc}
-0.381^{* * *} & -0.652^{* * *} \\
(0.146) & (0.143) \\
-0.529^{* * *} & -0.875^{* * *} \\
(0.131) & (0.141) \\
\text { omitted } & \text { omitted } \\
& \\
-0.570^{* * *} & -0.810^{* * *} \\
(0.149) & (0.179)
\end{array}
$$

$-0.808^{* * *}$

(0.346)

$-0.789^{* * *}$

(0.339)

$1.134^{* * *}$

(0.386)

$1.126^{* * *}$

(0.385)

$-0.186$

(0.202)

$-0.178$

(0.225)

$8.316^{* * *} \quad 9.641^{* * *} \quad 9.092^{* * *}$

$6.673^{* * *} \quad 8.116^{* * *} \quad 9.642^{* * *} \quad 9.026^{* * *}$

$\begin{array}{llllll}(0.655) & (0.539) & (0.098) & (0.827) & (0.763) & (0.746)\end{array}$

$4564 \quad 4564$

4401

4401

4401

4401

$28-27$

$27 \quad 27$

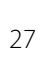

27

163

163

163

163

163 
Table 3 (continued)

\begin{tabular}{|c|c|c|c|c|c|c|c|c|}
\hline & \multicolumn{4}{|c|}{ Full sample } & \multicolumn{4}{|c|}{ Without Argentina } \\
\hline & (1) & (2) & (3) & (4) & (5) & (6) & (7) & (8) \\
\hline $\begin{array}{l}\text { Wald test } \\
\quad(p \text {-value })\end{array}$ & 0.000 & 0.000 & 0.000 & 0.000 & 0.000 & 0.000 & 0.000 & 0.000 \\
\hline $\begin{array}{c}\text { Adjusted } \\
R^{2}\end{array}$ & 0.73 & 0.76 & 0.77 & 0.78 & 0.74 & 0.76 & 0.77 & 0.78 \\
\hline
\end{tabular}

The table presents the effects of de jure and de facto political institutions on long-run development. The outcome variable is the natural log of per capita GDP (1990 Geary-Khamis international \$). Standard errors are adjusted for the serially correlated stochastic disturbances across and within countries using the finite-sample distribution function, intraclass multiway clustering scheme (Cameron et al. 2011). The asterisks denote statistically significant coefficients at 10 percent $(*)$, 5 percent $\left({ }^{* *}\right)$, and 1 percent $\left({ }^{* *}\right)$

most crucial differences in the paths of long-run development. The shift toward more pluralist, participatory, and open-access de jure political institutions and the effective enforcement of those institutions are associated with large and pervasive gains in per capita income, which do not seem to be linked to the broad set of control variables that systemically affect the paths of long-run development.

In columns (5) through (8), the set of model specifications from columns (1) through (4) is replicated on the sample excluding Argentina. The purpose of the replication is to check whether including Argentina makes a difference in the size and direction of the effects of de jure and de facto political institutions on long-run development. The evidence largely suggests that excluding Argentina from the core sample does not yield quantitatively and directionally different point estimates, even though it yields a 3.6 percent reduction in the sample size. The de jure and de facto estimates remain essentially balanced and unchanged compared to the set of specifications from columns (1) through (4). Hence, the point estimates from column (4) are used to build the counterfactual scenario to construct the path of Argentina's long-run development in the absence of institutional breakdowns.

\subsection{Cobb-Douglas production function estimates}

Table 4 reports the production function estimates of the augmented Solow growth model with physical and human capital stock measures along with the de jure and de facto institutional quality variables. Columns (1)-(4) report the set of estimated model specifications that nest the basic Solow growth model without the human capital stock. Consistent with the prior evidence on the Solow model, the estimates suggest strong and large effects of the capital stock on per capita output differences across countries. Conditional on the effect of capital accumulation, the estimated contribution of de jure institutional quality to long-run growth is between 2.9 and 3.3 percent, respectively, which appears to be consistent with the prior evidence without production factor variables. In columns (3) and (4), the estimated effect of de facto institutional quality to per capita output differences is noticeably smaller compared to the baseline estimates in Sect. 6.1. The production function estimates suggest that the contribution of de facto institutional quality is around 0.2 percent, which confirms our theoretical concerns about the upward biases of the OLS coefficients in crosscountry growth regression setup. 
Table 4 Cobb-Douglas production function estimates

\begin{tabular}{|c|c|c|c|c|c|c|c|c|}
\hline & \multicolumn{4}{|c|}{ With Solow-Swan restriction $(\alpha=0)$} & \multicolumn{4}{|c|}{ Without Solow-Swan restriction $(\alpha \neq 0)$} \\
\hline & (1) & $(2)$ & (3) & (4) & (5) & (6) & (7) & (8) \\
\hline $\ln (n+g+\delta)$ & $\begin{array}{r}-0.032^{*} \\
(0.019)\end{array}$ & $\begin{array}{r}-0.040^{*} \\
(0.022)\end{array}$ & $\begin{array}{r}-0.029 \\
(0.019)\end{array}$ & $\begin{array}{c}-0.031 \\
(0.023)\end{array}$ & $\begin{array}{c}-0.040^{* * *} \\
(0.017)\end{array}$ & $\begin{array}{c}-0.037^{* *} \\
(0.016)\end{array}$ & $\begin{array}{c}-0.035^{* *} \\
(0.017)\end{array}$ & $\begin{array}{r}-0.030^{*} \\
(0.016)\end{array}$ \\
\hline $\ln (k /)$ & $\begin{array}{r}0.722^{* * * *} \\
(0.023)\end{array}$ & $\begin{array}{r}0.701^{* * *} \\
(0.034)\end{array}$ & $\begin{array}{r}0.723^{* * *} \\
(0.025)\end{array}$ & $\begin{array}{r}0.704^{* * * *} \\
(0.039)\end{array}$ & $\begin{array}{r}0.646^{* * *} \\
(0.050)\end{array}$ & $\begin{array}{r}0.642^{* * *} \\
(0.052)\end{array}$ & $\begin{array}{r}0.646^{* * *} \\
(0.052)\end{array}$ & $\begin{array}{r}0.643^{* * * *} \\
(0.054)\end{array}$ \\
\hline $\ln (h / /)$ & & & & & & & $\begin{array}{c}0.190^{* *} \\
(0.096)\end{array}$ & $\begin{array}{c}0.218^{* *} \\
(0.099)\end{array}$ \\
\hline $\begin{array}{l}\text { De Jure } \\
\text { (latent) }\end{array}$ & $\begin{array}{r}0.029^{* * *} \\
(0.009)\end{array}$ & $\begin{array}{r}0.033^{* * *} \\
(0.009)\end{array}$ & & & $\begin{array}{r}0.026^{* * *} \\
(0.008)\end{array}$ & $\begin{array}{r}0.028^{* * *} \\
(0.008)\end{array}$ & & \\
\hline $\begin{array}{r}\text { De Facto } \\
\text { (latent) }\end{array}$ & & & $\begin{array}{l}0.002^{* * *} \\
(0.0007)\end{array}$ & $\begin{array}{c}0.002^{* * *} \\
(0.0008)\end{array}$ & & & $\begin{array}{l}0.001^{* *} \\
(0.0006)\end{array}$ & $\begin{array}{l}0.002^{* * *} \\
(0.0006)\end{array}$ \\
\hline $\begin{array}{l}\text { Latent } \\
\text { control } \\
\text { variables }\end{array}$ & Yes & Yes (0.719) & Yes $(0.790)$ & Yes $(0.778)$ & Yes $(0.951)$ & Yes (0.988) & Yes (0.948) & Yes $(0.981)$ \\
\hline $\begin{array}{l}\text { Common } \\
\text { Tech- } \\
\text { nology } \\
\text { Shocks }\end{array}$ & No & Yes $(0.000)$ & No & Yes $(0.000)$ & No $(0.000)$ & Yes $(0.000)$ & No & Yes $(0.000)$ \\
\hline $\begin{array}{l}\text { \# observa- } \\
\text { tions }\end{array}$ & 1674 & 1674 & 1674 & 1674 & 1674 & 1674 & 1674 & 1674 \\
\hline R2 & 0.93 & 0.93 & 0.93 & 0.93 & 0.94 & 0.94 & 0.94 & 0.94 \\
\hline
\end{tabular}

The table presents the augmented Solow growth model with de jure and de facto institutional quality for the period 19502012. Standard errors are adjusted for arbitrary heteroskedasticity and serially correlated stochastic disturbances using Huber-White sandwich estimator, and are denoted in the parentheses. Asterisks denote statistically significant coefficients at $10 \%\left({ }^{*}\right), 5 \%\left({ }^{* *}\right)$, and $1 \%\left({ }^{* *}\right)$, respectively

Columns (5)-(8) nest the augmented Solow growth model with human capital accumulation. The results confirm strong and positive first-order effects of physical capital accumulation and human capital investment on long-run growth differences across countries. In columns (5) and (6), adding the human capital investment variable to the Solow growth model, reduces the contribution of de jure institutional quality to 2.8 percent and 2.6 percent, respectively, depending on the confounding influence of common technology shocks. In columns (7) and (8), we show that the magnitude of the de facto institutional quality effect on per capita output is in the range between 0.1 and 0.2 percent, respectively. The evidence clearly suggests a partial remedy such as addressing the standard omitted variable bias, and the endogeneity concerns, renders the estimated OLS effects of de jure and de facto institutional quality on long-run growth and development biased upward. These biases are particularly acute when considering the effect of de facto political institutions on long-run growth, which appears to be somewhat more important in the set of baseline estimates.

\subsection{Counterfactual outcomes}

What would Argentina's long-run development look like in the absence of institutional breakdowns? Table 5 presents the composition of the synthetic control group used to assess Argentina's long-run development path in the absence of the institutional breakdowns summarized in Table 1 . The synthetic setup replicates the specification from column (8) in Table 3 and adds the initial level of de jure and de facto institutions to the specification. The composition of the synthetic control group appears to be relatively 
stable across different breakdown dates and does not seem to shift from the baseline when the synthetic counterfactual is replicated for the 1912 Sáenz Peña Law. For the period after the passage of the Sáenz Peña Law, the synthetic control unit consists of the weighted covariate-level mean of Germany (43.8 percent), Chile (35.4 percent), the United States (17.6 percent), and Mexico (3.2 percent). A similar composition is indicated for the 1930 military coup, with Chile, the United States, and Uruguay composing the key donor pool. For the 1946 rise of Perón, Chile, Uruguay, and Switzerland are the key donor countries, whereas for the 1975 military dictatorship, Switzerland, Chile, Uruguay, and Mexico make up the synthetic control group. Across all breakdowns, Chile appears to be one of the largest donor countries, followed by the United States, Uruguay, Switzerland, Germany, and Mexico. For each synthetic counterfactual scenario, the root-mean-square prediction error from the nested specification appears to be very low and stable, ranging from 0.13 for the second Perón era to 0.08 for the 1975 military dictatorship.

In Table 6, a summary of the long-run development scenarios without institutional breakdowns is presented. The counterfactual estimates indicate large per capita income gains over time in the absence of key institutional breakdowns and largely suggest that, without such breakdowns, Argentina would currently be among the rich countries if it had followed the institutional development trends of the key donor countries. By 2012, Argentina's per capita income was about 34 percent of that of the United States. The synthetic counterfactuals suggest that without the 1930 military coup, Argentina's long-run per capita income would have approached 59 percent of the US level by 2012, which is equivalent to the income level of New Zealand or Slovenia. In the absence of Perón's rise to power in 1946, Argentina's long-run per capita income would have reached 53 percent of the US level by 2012. In per capita income terms, this income level is equivalent to that of Spain or Italy. A similar long-run development level would have been achieved in the absence of post-World War II institutional ruptures such as the 1954 Revolución Libertadora, the 1958 onset of a series of fragile UCR administrations, the 1965 transition to the authoritarian-bureaucratic state (Revolución Argentina), Perón's second rise to power, and the 1975-1983 military dictatorship. Had the institutional breakdowns never occurred and had Argentina's development instead paralleled the trends in donor countries such as Germany, the United States, Switzerland, Uruguay, and Chile, its longrun per capita income would most likely have exceeded 50 percent of the US level. The synthetic control estimates used here imply that such a drastic long-run change in the development path would have shifted Argentina from its status today as an underdeveloped, upper-middle-income country to that of a rich country, with its income level on the same footing as that of Spain, Italy, Slovenia, and New Zealand. The counterfactual estimations imply that, in the absence of the key institutional breakdowns, Argentina's per capita output growth rate would move from 1.34 percent to 1.69 percent, which is the equivalent of a 26 percent increase in its long-run growth rate. In the years between 1850 and 2012, such a quantitative shift in the growth rate would have narrowed Argentina's per capita income shortfall relative to the United States by between 14 and 25 percentage points, depending on the breakdown's timing and type.

As a robustness check, the study replicates the counterfactual scenario for the 1912 Sáenz Peña Law to gauge how the long-term implications of the initial and short-lived 
Table 5 Synthetic control group across institutional breakdowns

\begin{tabular}{|c|c|c|c|c|c|c|c|c|c|}
\hline & $\begin{array}{l}1912 \\
\text { Sáenz } \\
\text { Peña } \\
\text { Law }\end{array}$ & $\begin{array}{l}1930 \\
\text { military } \\
\text { coup }\end{array}$ & $\begin{array}{l}1946 \text { rise } \\
\text { of Perón }\end{array}$ & $\begin{array}{l}1954 \\
\text { Revolución } \\
\text { Libertadora }\end{array}$ & $\begin{array}{l}1958 \text { fragile } \\
\text { radical (UCR) } \\
\text { administrations }\end{array}$ & $\begin{array}{l}1965 \\
\text { Revolución } \\
\text { Argentina }\end{array}$ & $\begin{array}{l}1972 s \\
\text { Perón } \\
\text { era }\end{array}$ & $\begin{array}{l}1975 \\
\text { military } \\
\text { dictatorship }\end{array}$ & $\begin{array}{l}1983 \\
\text { transition } \\
\text { to democracy }\end{array}$ \\
\hline $\begin{array}{l}\text { Root } \\
\text { MSPE }\end{array}$ & 0.12 & 0.11 & 0.11 & 0.08 & 0.12 & 0.11 & 0.13 & 0.08 & 0.10 \\
\hline Austria & - & - & - & - & - & - & - & - & - \\
\hline Belgium & - & - & - & - & - & 0.108 & - & - & - \\
\hline Brazil & - & - & - & - & - & - & 0.003 & - & - \\
\hline Chile & 0.354 & 0.501 & 0.360 & 0.098 & 0.334 & 0.488 & 0.346 & 0.288 & 0.159 \\
\hline China & - & - & - & - & - & - & - & - & - \\
\hline $\begin{array}{l}\text { Colom- } \\
\text { bia }\end{array}$ & - & - & - & - & - & - & - & - & - \\
\hline Denmark & - & - & - & - & - & 0.209 & - & - & 0.204 \\
\hline France & - & - & - & - & - & - & - & - & - \\
\hline Germany & 0.438 & 0.222 & - & - & 0.180 & - & 0.081 & - & - \\
\hline Greece & - & - & - & - & - & - & - & - & - \\
\hline Iran & - & - & 0.040 & - & - & - & 0.004 & - & - \\
\hline Italy & - & - & - & - & - & - & - & - & - \\
\hline Japan & - & - & - & - & - & - & - & - & - \\
\hline Mexico & 0.032 & 0.002 & & 0.327 & 0.063 & & & 0.206 & \\
\hline Nepal & - & - & - & - & - & - & - & - & - \\
\hline $\begin{array}{l}\text { Nether- } \\
\text { lands }\end{array}$ & - & - & - & - & - & - & - & - & - \\
\hline Norway & - & - & - & - & - & - & - & - & - \\
\hline Portugal & - & - & - & - & - & - & - & - & - \\
\hline Spain & - & - & - & - & - & - & - & - & - \\
\hline Sweden & & & 0.085 & - & - & - & - & - & - \\
\hline $\begin{array}{l}\text { Switzer- } \\
\text { land }\end{array}$ & & & 0.181 & 0.457 & - & - & 0.117 & 0.361 & - \\
\hline Thailand & - & - & - & - & - & - & - & - & - \\
\hline Turkey & - & - & - & - & - & - & - & - & - \\
\hline $\begin{array}{l}\text { United } \\
\text { King- } \\
\text { dom }\end{array}$ & - & - & - & - & - & - & - & - & - \\
\hline $\begin{array}{l}\text { United } \\
\text { States }\end{array}$ & 0.176 & 0.211 & 0.075 & - & 0.254 & 0.105 & 0.023 & - & 0.479 \\
\hline Uruguay & - & 0.064 & 0.258 & 0.117 & 0.169 & 0.090 & 0.426 & 0.145 & 0.157 \\
\hline $\begin{array}{l}\text { Ven- } \\
\text { ezuela }\end{array}$ & - & - & - & - & - & - & - & - & - \\
\hline
\end{tabular}

MSPE mean-square prediction error

transition to democracy differ from the breakdown implications. The evidence largely suggests that, compared to the countries on the parallel trend line, the synthetic Argentina exhibits a markedly higher per capita income level in the long run. In quantitative terms, Argentina's long-run per capita income in the absence of the Sáenz Peña Law would approach 62 percent of the US level, which is nearest to that of New Zealand. Before passage of the 1912 law, Argentina's development path appears to closely match the paths of Chile, Germany, the United States, and Uruguay. Contrary to widespread belief, the evidence supports the notion that such a transition to democracy might also have encouraged the wealth and income redistribution that led to effects on long-run development that were just as harmful as the institutional breakdowns that started with the 1930 coup. The synthetic counterfactual estimates here clearly suggest that if, instead of enactment of the 1912 Sáenz Peña Law, Argentina's institutional development 
Table 6 Argentina's long-run development without institutional breakdowns

\begin{tabular}{|c|c|c|c|c|c|c|}
\hline & \multicolumn{2}{|c|}{$\begin{array}{l}\text { Real GDP per capita } \\
\text { in } 2012 \text { ( } 1990 \text { Geary- } \\
\text { Khamis international \$) }\end{array}$} & \multicolumn{2}{|c|}{$\begin{array}{l}\text { Ratio of real GDP } \\
\text { per capita relative } \\
\text { to the United States } \\
\text { in } 2012\end{array}$} & \multicolumn{2}{|c|}{$\begin{array}{l}\text { Long-run growth rate } \\
\text { (mean and standard } \\
\text { deviation) }\end{array}$} \\
\hline & Real & Counterfactual & Real & Counterfactual & Real & Counterfactual \\
\hline 1912 Sáenz Peña Law & 10,990 & 19,372 & 0.34 & 0.62 & $1.34(5.82)$ & $1.69(4.81)$ \\
\hline 1930 military coup & 10,990 & 18,564 & 0.34 & 0.59 & $1.34(5.82)$ & $1.69(4.52)$ \\
\hline 1946 rise of Perón & 10,990 & 16,647 & 0.34 & 0.53 & $1.34(5.82)$ & $1.69(4.81)$ \\
\hline 1954 Revolución Libertadora & 10,990 & 15,137 & 0.34 & 0.49 & $1.34(5.82)$ & $1.58(3.68)$ \\
\hline $\begin{array}{l}1958 \text { fragile radical (UCR) } \\
\text { administrations }\end{array}$ & 10,990 & 17,806 & 0.34 & 0.57 & $1.34(5.82)$ & $1.63(3.89)$ \\
\hline 1965 Revolución Argentina & 10,990 & 18,540 & 0.34 & 0.59 & $1.34(5.82)$ & $1.65(3.88)$ \\
\hline 1972s Perón era & 10,990 & 15,106 & 0.34 & 0.48 & $1.34(5.82)$ & $1.51(4.28)$ \\
\hline 1975 military dictatorship & 10,990 & 15,524 & 0.34 & 0.49 & $1.34(5.82)$ & $1.51(3.67)$ \\
\hline 1983 transition to democracy & 10,990 & 17,822 & 0.34 & 0.57 & $1.34(5.82)$ & $1.64(3.98)$ \\
\hline
\end{tabular}

mimicked that of the key donor countries, its long-run per capita income gains would have been large, and today Argentina would be a rich country. Figure 3 summarizes the synthetic counterfactual scenario for each quantified institutional breakdown.

\subsection{Robustness checks}

This section briefly discusses the alternative difference-in-differences (DD) counterfactual setup of the long-run development model as a robustness check on the validity of synthetic control estimates.

\subsubsection{Difference-in-differences counterfactual setup}

As a robustness check on the validity of synthetic control estimates, the difference-indifferences effects of Argentina's institutional breakdown on long-run development were computed and the set of counterfactual estimates was constructed. A calibration of the DD parametric estimates is performed to examine the alternative paths of Argentina's development under two plausible assumptions: (a) the absence of institutional breakdowns and (b) the adoption of US-style de jure and de facto political institutions over a 15 -year transition window.

Let $i=1,2, \ldots N$ index the number of countries in the sample. Suppose the de jure and de facto institutional breakdowns take place in country $j$ at time $t$. Assume country $j$ at time $t+1$ embarks on a different institutional path from a nearest-neighbor country with similar observable characteristics. First, to gauge the effects of institutional breakdowns, use the following equation to show the underlying counterfactual distribution of the de jure and de facto set of political institutions:

$$
\begin{aligned}
& \mathfrak{\Im}_{j, t}^{\text {De Jure, Counterfactual }}= \begin{cases}\mathrm{I}_{j, t}^{\text {De Jure }} & \text { if } t<t_{0}^{\text {Breakdown }} \\
\mathrm{I}_{\mathrm{US}, t}^{\text {De Jure }} & \text { if } t>t_{0}^{\text {Breakdown }}\end{cases} \\
& \mathfrak{\Im}_{j, t}^{\text {De Facto, Counterfactual }} \\
& = \begin{cases}\mathrm{I}_{j, t}^{\text {De Facto }} & \text { if } t<t_{0}^{\text {Breakdown }} \\
\mathrm{I}_{\mathrm{US}, t}^{\text {De Facto }} & \text { if } t>t_{0}^{\text {Breakdown }}\end{cases}
\end{aligned}
$$


where the set of de jure and de facto political institutions in the $j$-th country in the postbreakdown years is replaced by the set of political institutions from the $i$-th benchmark country-in this case the United States. Second, invoke the core fixed effects long-run development in Eq. (8), and consider the estimated de jure and de facto coefficients. Third, for Argentina as the treated unit, construct an alternative de jure and de facto institutional time series, where the level of development of the de jure and de facto political institutions moves to the US level in $t+1$ during the 15-year transition period. Fourth, use the de jure and de facto long-run development point estimates, and compute the path of long-run development with the alternative time series in the postbreakdown period conditional on the observed covariates and their point estimates in Table 3. Using the spliced de jure and de facto institutional time series for Argentina, one can compute the counterfactual path of long-run development as:

$$
\begin{aligned}
\ln \widehat{y}_{j, t}^{\text {Counterfactual }}= & \tilde{\Omega}+\left(\tilde{\theta}_{1} \cdot \Im_{j, t}^{\text {De Jure, Counterfactual }}+\tilde{\theta}_{2} \cdot \Im_{j, t}^{\text {De Facto, Counterfactual }}\right)+\Delta_{j}, \\
& +\sum_{j=1}^{J} \tilde{\mu}_{j} \cdot 1[j \rightarrow\{0,1\}]+\sum_{t=1}^{T} \tilde{\phi}_{t} \cdot 1[t \rightarrow\{0,1\}]+\mathbf{X}_{j, t}^{\prime} \tilde{\beta}+\varepsilon_{j, t},
\end{aligned}
$$

where $\widehat{y}_{j, t}^{\text {Counterfactual }}$ is the counterfactual path of long-run development for the $j$-th country (Argentina) at time $t ; \tilde{\theta}_{1}$ and $\tilde{\theta}_{2}$, respectively, denote the point estimates for de jure and de facto political institutions to long-run development from Eq. (3.1); $\tilde{\mu}_{j}$ denotes the shift in the intercept $\tilde{\Omega}$ triggered by unobserved country-level effects, which varies across countries; $\tilde{\phi}$ denotes the shift in $\tilde{\Omega}$ triggered by the time-varying technology shocks common across all countries; $\tilde{\beta}$ indicates the estimated effects of long-run development covariates different from political institutions; and $\Delta_{j}$ denotes the cyclical variation in $y$ captured by the log first differences of per capita GDP that take place even with the alternative de jure and de facto institutional design. By default, Eq. (14) implies that the counterfactual long-run development series exactly matches the actual one in the pre-breakdown period but tends to offset it in the postbreakdown period.

In Additional file 1: Table S1 summarizes the DD effects of institutional breakdowns on Argentina. If Argentina had had US-style de jure and de facto political institutions in place since 1850, the counterfactual estimate implies that its long-run per capita output would have been 45 percent higher than the actual one by the end of the estimation period. Such a sizable gain in long-run growth and development following the US-style institutional design implies that Argentina's per capita output relative to that of the United States would rise from 34 percent to roughly 50 percent. The DD estimates of Argentina's long-run development without institutional breakdowns are slightly smaller but roughly similar to the synthetic control estimates in Fig. 3 and Table 5.

\section{Conclusion}

This paper exploits moments of institutional breakdown to consistently estimate the contribution of de jure and de facto political institutions to long-run development. Drawing on Argentina's extensive historical bibliography, the empirical strategy used here identifies the moments of institutional breakdown and builds a counterfactual scenario assuming Argentina developed de jure and de facto political institutions such as 


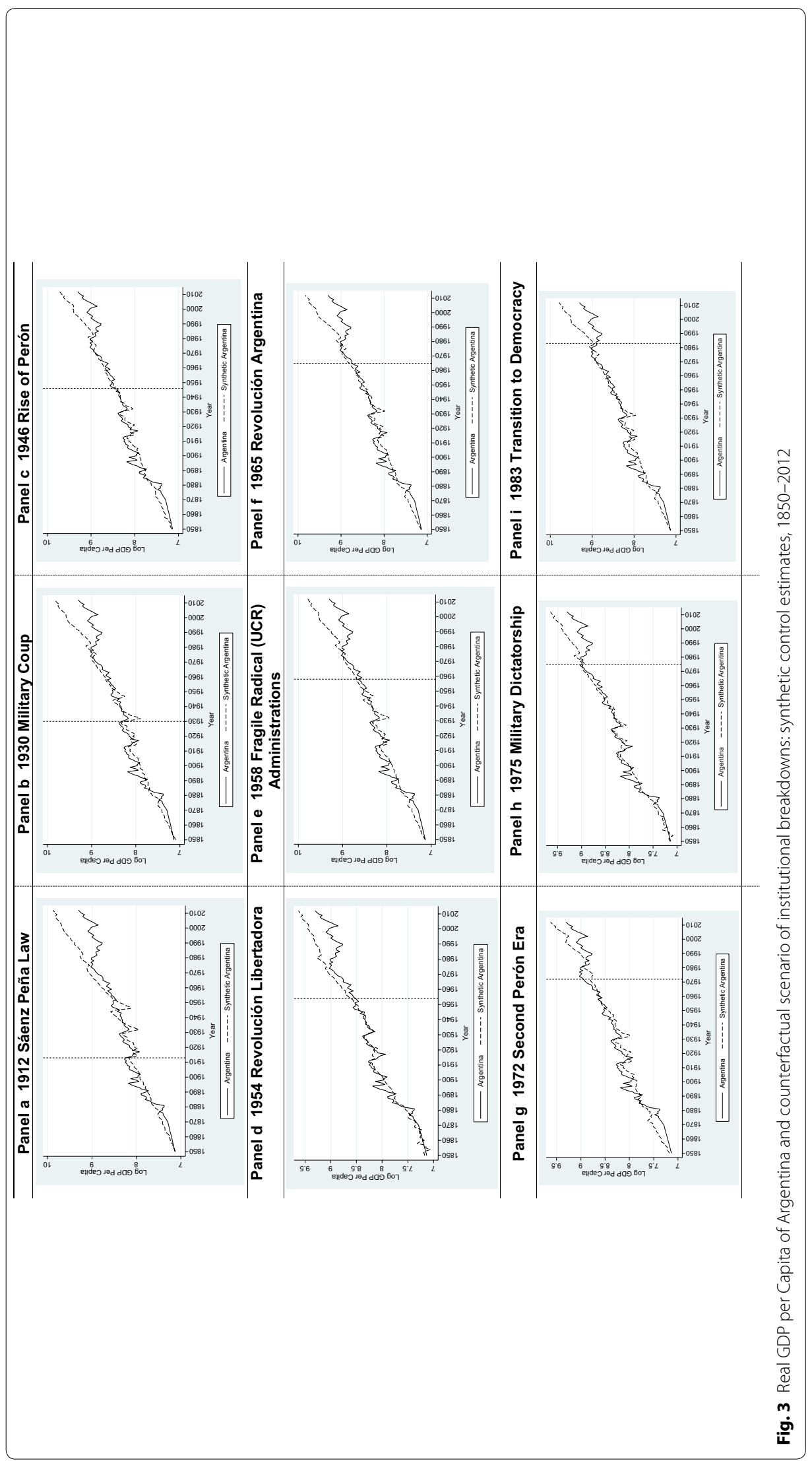


those that developed in similar countries, including competitive polity, genuine rule of law, checks and balances, and an independent Supreme Court. The 1853 Constitution enshrined many principles from the US republican model, and Argentina embarked on the path of its Belle Époque. It achieved remarkable rates of economic growth but never finished its transition to democracy. Decades of electoral fraud, political malfeasance, and legislative malapportionment were put to a halt in 1912 upon the passage of the Sáenz Peña Law, which outlawed fraud and introduced secret, compulsory male suffrage. Although democracy tends to accompany the rule of law and greater transparency, by the same token, the Sáenz Peña Law also sowed the seeds for income and wealth redistribution and helped to pave the way for the populist-style public policies that also condoned the institutional breakdowns that followed. Argentina's transition to democracy was formally infringed in the 1930 military coup, which precipitated a decade of electoral fraud, brought about the demise of checks and balances, and later led to Juan Perón's rise to power. This paper shows that Argentina's departure from the system of checks and balances and its abandonment of the rule of law triggered a series of persistent institutional breakdowns and held long-lasting implications for the country's growth and development for many years ahead.

Had the institutional breakdowns not occurred and had Argentina followed the trends established in similar countries in developing de jure and de facto political institutions, its per capita output would have improved dramatically. In the long run, the absence of institutional breakdowns is associated with a 45 percent increase in per capita output. Such a large gain is the equivalent of Argentina's departure from a middle-income country into the ranks of Spain and Italy. In the counterfactual scenario, the long-run benefits of an absence of institutional breakdowns are pervasive, robust, and large-scale improvements in long-run development. Had the Sáenz Peña Law not facilitated populist-style income and wealth redistribution, the synthetic control estimates here imply that today Argentina's per capita income would approach 62 percent of the US level, which is comparable to that of New Zealand or Slovenia. Instead, Argentina perpetuated nearly a century of institutional instability that undermined the security of property rights, increased transaction costs, and essentially led to the abandonment of the rule of law. Starting with the rise to power of Perón and his influential wife Eva, Argentina embarked on an irreversible path of populist social and economic policies and divideand-rule politics that ignited Argentina's decline. The institutional breakdowns triggered by powerful elites were chiefly characterized by uninterrupted forced resignations of Supreme Court justices, declaration of economic and political emergencies, nationalization of firms, prosecution and torture of political opponents, nullification of the 1853 Constitution, rampant government favoritism, and media censorship.

Had the 1930 military coup never happened, and had Argentina avoided the subsequent institutional breakdowns and the populist Peronist-style divide-and-rule politics, the synthetic control and difference-in-differences estimates described herein imply that the country would have experienced a robust upward growth. In the absence of institutional breakdowns, Argentina's per capita income would have approached the ranks of New Zealand, Spain, and Italy.

The implications of this analysis are that having de jure and de facto political institutions borrowed from a benchmark country such as the United States would not have 
prevented Argentina's century of decline following the US growth spurt. The limited data on the layers of economic, legal, and other types of institutions preclude a systematic counterfactual investigation of an alternative development path with a different set of economic and legal institutions and public policies than the actual ones. From the normative perspective, the analysis highlights important interplay between the de jure and de facto political institutions, institutional breakdowns, and long-run development. First, the effects of institutional breakdowns such as the forced resignation of Supreme Court justices are unlikely to disappear. They hold negative, long-lasting implications for the path of growth and development and may trigger the adverse side of path dependence. Second, technological and development breakthroughs are unlikely to be nurtured by broad-based and pluralist de jure and de facto political institutions per se because such institutions may be insufficient to create a framework based on secure property rights and low transaction costs that could underpin the path to sustained growth. Third, the onset of institutional breakdowns typically invokes rampant government favoritism of powerful groups in the absence of constraints on the various sources of power. Such favoritism-first in the form of the populist-style policies that proliferated under Perón and second in the form of shifts back and forth between democracy and dictatorshipproved detrimental, as it condemned Argentina to comparative decline and economic stagnation, expanding its per capita output shortfall relative to benchmark countries such as the United States to previously unimaginable levels.

This study provides one of the first attempts to systematically assess the long-run development costs of institutional breakdowns. Given its inherent limitations, four related issues remain unclear. First, why do some societies fall into the trap of institutional breakdowns while others manage to attain stable, broad-based, and enduring de jure and de facto political institutions? Second, do institutional breakdowns affect the proximate causes of growth and development such as human capital formation, physical capital formation, and demographic changes? Third, how long does it take for societies to recover economically from institutional breakdowns? And fourth, are institutional breakdowns outside Argentina fundamentally different and, if so, in what ways? Given the limitations inherent in this paper, these perplexing questions provide fruitful venues for future research.

\section{Supplementary information}

Supplementary information accompanies this paper at https://doi.org/10.1186/s40503-019-0076-2.

Additional file 1: Table S1. Argentina's Long-Run Development without Institutional Breakdowns. Figure S1. Real GDP per Capita of Argentina and Counterfactual under US-Style Institutional Design in the Absence of Institutional Breakdowns, 1850-2012

Acknowledgements

The author would like to thank Hector Nuñez for excellent editorial guidance. I would also like to thank Robert Barro, Nuno Garoupa, Nita Ghei, Gregory Fitton, Scott Eastman, Tobias M. Hlobil, Mitja Kovac, Maximilliano Marzetti, Kris Mitchener, Wolfgang Weigel, and four anonymous referees for their comments, suggestions, and feedback on an early draft version of this paper.

Authors' contributions

The author read and approved the final manuscript.

Funding

The author would like to thank Mercatus Center at George Mason University for the financial support. 
Availability of data and materials

If the paper is accepted for publication, the dataset will be uploaded onto the data repository (i.e. Harvard Dataverse) with the full statistical code of the results to facilitate and encourage the replication.

\section{Competing interests}

The author declares that they have no competing interests.

Received: 17 September 2018 Accepted: 29 October 2019

Published online: 15 November 2019

\section{References}

Abadie A, Diamond A, Hainmueller J (2010) Synthetic control methods for comparative case studies: estimating the effect of California's tobacco control program. J Am Stat Assoc 105(490):493-505

Acemoglu D, Robinson JA (2000) Why did the west extend the Franchise? Democracy, inequality, and growth in historical perspective. Quart J Econ 115(4):1167-1199

Acemoglu D, Robinson JA (2001) Inefficient redistribution. Am Polit Sci Rev 95(3):649-661

Acemoglu D, Robinson JA (2006a) De Facto political power and institutional persistence. Am Econ Rev 96(2):325-330

Acemoglu D, Robinson JA (2006b) Economic origins of dictatorship and democracy. Cambridge University Press, New York

Acemoglu D, Robinson JA (2012) Why nations fail: the origins of power, prosperity, and poverty. Crown Business, New York

Acemoglu D, Johnson S, Robinson JA (2001) The colonial origins of comparative development: an empirical investigation. Am Econ Rev 91(5):1369-1401

Acemoglu D, Johnson S, Robinson JA (2002) Reversal of fortune: geography and institutions in the making of modern world income distribution. Quart J Econ 117(4):1231-1294

Acemoglu D, Johnson S, Robinson JA, Thaicharoen Y (2003) Institutional causes, macroeconomic symptoms: volatility, crises and growth. J Monetary Econ 50(1):49-123

Acemoglu D, Johnson S, Robinson JA, Yared P (2005) From education to democracy? Am Econ Rev 95(2):44-49

Adelman J (1992) Reflections on Argentine labour and the rise of Perón. Bull Latin Am Res 11(3):243-259

Adelman J (1994) Frontier development: land, labour, and capital on the wheatlands of Argentina and Canada, 1890-1914. Oxford University Press, New York

Adelman J (1999) Republic of capital: Buenos Aires and the legal transformation of the atlantic world. Stanford University Press, Stanford

Aghion P, Caroli E, García-Peñalosa C (1999) Inequality and economic growth: the perspective of the new growth theories. J Econ Lit 37(4):1615-1660

Alesina A, Rodrik D (1994) Distributive politics and economic growth. Quart J Econ 109(2):465-490

Alesina A, Devleeschauwer A, Easterly W, Kurlat S, Wacziarg R (2003) Fractionalization. J Econ Growth 8(2):155-194

Algan Y, Cahuc P (2010) Inherited trust and growth. Am Econ Rev 100(5):2060-2092

Alhadeff P (1989) Social welfare and the slump: Argentina in the 1930s. In: Platt DCM (ed) Social welfare, 1850-1950: Australia, Argentina and Canada Compared. Palgrave Macmillan, London, pp 169-178

Alston LJ, Gallo AA (2010) Electoral fraud, the rise of Perón and demise of checks and balances in Argentina. Explor Econ Hist 47(2):179-197

Alston LJ, Mueller B (2006) Pork for policy: executive and legislative exchange in Brazil. J Law Econ Organ 22(1):87-114 Andrien KJ (1982) The sale of fiscal offices and the decline of royal authority in the viceroyalty of Peru, 1633-1700. Hisp Am Hist Rev 62(1):49-71

Andrien KJ (1984) Corruption, inefficiency, and imperial decline in the seventeenth-century viceroyalty of Peru. Americas 41(1):1-20

Arceneaux CL (1997) Institutional design, military rule, and regime transition in Argentina (1976-1983): an extension of the remmer thesis. Bull Latin Am Res 16(3):327-350

Arellano M (1987) Computing robust standard errors for within-groups estimators. Oxford Bull Econ Stat 49(4):431-434

Ashraf Q, Galor O (2013) The 'Out of Africa' hypothesis, human genetic diversity, and comparative economic development. Am Econ Rev 103(1):1-46

Austin G (2008) The 'Reversal of Fortune'thesis and the compression of history: perspectives from African and comparative economic history. J Int Dev 20(8):996-1027

Azcuy Ameghino E (2002) La otra historia: Economía, Estado y Sociedad en el Río de la Plata Colonial. Ediciones Imago Mundi, Buenos Aires

Bambaci J, Saront T, Tommasi M (2002) The political economy of economic reforms in Argentina. J Policy Reform 5(2):75-88

Barro RJ (1999) Determinants of democracy. J Polit Econ 107(S6):158-183

Barro RJ, Lee JW (2013) A new data set of educational attainment in the world, 1950-2010. J Dev Econ 104:184-198

Baskes J (2000) Indians, merchants, and markets: a reinterpretation of the repartimiento and Spanish-Indian economic relations in Colonial Oaxaca, 1750-1821. Stanford University Press, Stanford

Bayle C (1952) Los cabildos seculares en la América española. Sapientia, Madrid

Becker SO, Woessmann L (2009) Was weber wrong? A human capital theory of protestant economic history. Quart J Econ 124(2):531-596

Berkowitz D, Pistor K, Richard J-F (2003a) Economic development, legality, and the transplant effect. Eur Econ Rev 47(1):165-195

Berkowitz D, Pistor K, Richard J-F (2003b) The transplant effect. Am J Comp Law 51(1):163-203 
Bértola L, Ocampo JA (2012) The economic development of Latin America since independence. Oxford University Press, New York

Bertrand M, Duflo E, Mullainathan S (2004) How much should we trust differences-in-differences estimates? Quart J Econ 119(1):249-275

Bethell L (1993) Argentina since independence. Cambridge University Press, New York

Bloom DE, Sachs JD (1998) Geography, demography, and economic growth in Africa. Brook Pap Econ Act 1998(2):207-295

Bollen KA (1990) Political democracy: conceptual and measurement traps. Stud Comp Int Dev 25(1):7-24

Bolt J, van Zanden JL (2014) The Maddison project: collaborative research on historical national accounts. Econ Hist Rev 67(3):627-651

Brennan JP, Rougier M (2009) The politics of national capitalism: Peronism and Argentine Bourgeoisie, 1946-1976. Penn State Press, University Park

Bruhn M, Gallego FA (2012) Good, bad, and ugly colonial activities: do they matter for economic development? Rev Econ Stat 94(2):433-461

Buchanan PG (1985) State corporatism in Argentina: labor administration under Perón and Onganía. Latin Am Res Rev 20(1):61-95

Burkholder MA, Chandler DS (1977) From impotence to authority: the Spanish crown and the American Audiencias, 1687-1808. University of Missouri Press, Columbia

Calvo E, Murillo MV (2004) Who delivers? Partisan clients in the Argentine electoral market. Am J Polit Sci 48(4):742-757

Cameron AC, Trivedi PK (2005) Microeconometrics: methods and applications. Cambridge University Press, Cambridge

Cameron AC, Gelbach JB, Miller DL (2011) Robust inference with multiway clustering. J Bus Econ Stat 29(2):238-249

Campos NF, Karanasos MG, Tan B (2012) Two to tangle: financial development, political instability and economic growth in Argentina. J Bank Finance 36(1):290-304

Cantón D (1973) Elecciones y partidos políticos en la Argentina: Interpretación y balance, 1910-1966. Siglo XXI, Buenos Aires

Cantú F, Saiegh SM (2011) Fraudulent democracy? An analysis of Argentina's infamous decade using supervised machine learning. Polit Anal 19(4):409-433

Chavez RB (2004) the evolution of judicial autonomy in Argentina: establishing the rule of law in an ultrapresidential system. J Latin Am Stud 36(3):451-478

Ciria A (1974) Parties and power in modern Argentina 1930-1946. SUNY Press, Albany

Clague C, Keefer P, Knack S, Olson M (1999) Contract-intensive money: contract enforcement, property rights, and economic performance. J Econ Growth 4(2):185-211

Collier RB, Collier D (2004) Shaping the political arena: Critical junctures, the labor movement and regime dynamics in Latin America. Princeton University Press, Princeton

Colomer JM (2004) Taming the tiger: voting rights and political instability in Latin America. Latin Am Polit Soc 46(2):29-58

Cook CJ (2014) The role of lactase persistence in precolonial development. J Econ Growth 19(4):369-406

Cortés Conde R (1998a) Fiscal Crisis and Inflation in XIX Century Argentina. Documento de Trabajo 18. Universidad de San Andrés, Buenos Aires

Cortés Conde R (1998b) Progreso y declinación de la economía argentina: Un análisis histórico institucional. Fondo de Cultura Económica, Buenos Aires

Crassweller RD (1988) Perón and the Enigmas of Argentina. Norton, New York

Crawley E (1984) A house divided: Argentina, 1880-1980. St. Martin's Press, New York

Cronbach LJ (1951) Coefficient alpha and the internal structure of tests. Psychometrika 16(3):297-334

Davis P (2002) Estimating multi-way error components models with unbalanced data structures. J Econom 106(1):67-95

de Privitello L, Romero LA (2000) Grandes discursos de la historia Argentina. Aguilar, Buenos Aires

de Velasco JAM (1983) Relación y documentos de gobierno del virrey del Perú, José A. Manso de Velasco, conde de Superunda (1745-1761). Editorial CSIC, Madrid

Dell M, Jones BF, Olken BA (2012) Temperature shocks and economic growth: evidence from the last half century. Am Econ J: Macroecon 4(3):66-95

della Paolera G, Taylor AM (1999) Economic recovery from the Argentine great depression: institutions, expectations, and the change of macroeconomic regime. J Econ Hist 59(3):567-599

Di Tella G (1983) Argentina under Perón, 1973-76: the nation's experience with a labour-based government. Macmillan, London

Di Tella TS (1998) Historia social de la Argentina contemporanea. Troquel, Buenos Aires

Di Tella G, Platt DCM (eds) (1986) The political economy of Argentina, 1880-1946. Palgrave Macmillan, London

Di Tella G, Zymelman M (1967) Las etapas del desarrollo económico argentino. Editorial Universitaria de Buenos Aires, Buenos Aires

Di Tella R, Glaeser EL, Llach L (2013) Introduction to Argentine exceptionalism exceptional Argentina. Latin Am Econ Rev 27(1):1-22

Díaz Alejandro CF (1970) Essays on the economic history of the Argentine Republic. Yale University Press, New Haven

Díaz Alejandro CF (1985) Argentina, Australia and Brazil before 1929. In: Platt DCM, di Tella G (eds) Argentina, Australia and Canada: studies in comparative development. Palgrave Macmillan, London, pp 95-109

Díaz Bessone RG (1986) Guerra revolucionaria en la Argentina (1959-1978). Editorial Fraterna, Buenos Aires

Duncan T, Fogarty J (1984) Australia and Argentina: on parallel paths. Melbourne University Press, Melbourne

Eaton KH (2002) Fiscal policy making in the Argentine legislature. In: Morgenstern S, Nacif B (eds) Legislative politics in Latin America. Duke University Press, Durham, pp 287-314

Eder PJ (1949) Impact of the common law on Latin America. Miami Law Quart 4(4):435-440

Elena E (2007) Peronist consumer politics and the problem of domesticating markets in Argentina, 1943-1955. Hisp Am Hist Rev 87(1):111-149

Elizagaray AA (1985) The political economy of a populist government: Argentina, 1943-55. PhD diss., University of Illinois at Urbana-Champaign 
Engerman SL, Sokoloff KL (1997) Factor endowments, institutions and differential paths of growth among the new world economies. In: Haber S (ed) How Latin America fell behind. Stanford University Press, Stanford, pp 260-306

Engerman SL, Sokoloff KL (2005) The evolution of suffrage institutions in the new world. J Econ Hist 65(4):891-921 Evans G, Rose P (2007) Support for democracy in Malawi: does schooling matter? World Dev 35(5):904-919

Fayt CA (1967) La naturaleza del Peronismo. Editorial Viracocha, Buenos Aires

Feenstra RC, Inklaar R, Timmer MP (2015) The next generation of the Penn World Table. Am Econ Rev 105(10):3150-3182

Feld LP, Voigt S (2003) Economic growth and judicial independence: cross-country evidence using a new set of indicators. Eur J Polit Econ 19(3):497-527

Ferns HS (1969) Argentina. Praeger, New York

Ferrero RA (1976) Del fraude a soberania popular, 1938-1946. La Bastilla, Buenos Aires

Feyrer J, Sacerdote B (2009) Colonialism and modern income: islands as natural experiments. Rev Econ Stat 91(2):245-262

Földvári P (2016) De Facto versus de Jure Political Institutions in the long-run: a multivariate analysis, 1820-2000. Soc Indic Res 130(2):759-777

Friedman M (1962) Capitalism and freedom. University of Chicago Press, Chicago

Fukuyama F (ed) (2008) Falling behind: explaining the development gap between Latin America and the United States. Oxford University Press, Oxford

Fukuyama F (2014) Political order and political decay: from the industrial revolution to the globalization of democracy. Macmillan, London

Gallo E (1983) La pampa gringa: La colonización agrícola en Santa Fe (1870-1875). Editorial Sudamericana, Buenos Aires

Gallo E (1993) Society and politics, 1880-1916. In: Bethell L (ed) Argentina since independence. Cambridge University Press, New York, pp 79-112

Gallo AA, Alston LJ (2008) Argentina's abandonment of the rule of law and its aftermath. Wash Univ J Law Policy 26:153-182

Gallup JL, Sachs JD, Mellinger AD (1999) Geography and economic development. Int Reg Sci Rev 22(2):179-232

Garavaglia JC, Gelman JD (1995) Rural history of the Rio de la Plata, 1600-1850: results of a historiographical renaissance. Latin Am Res Rev 30(3):75-105

Garay AF (1991) Federalism, the judiciary, and constitutional adjudication in Argentina: a comparison with the US constitutional model. Univ Miami Inter-Am Law Rev 22(2-3):161-202

García Hamilton JI (2005) Historical reflections on the splendor and decline of Argentina. Cato J 25(3):521-540

Gerchunoff P, Díaz Alejandro CF (1989) Peronist economic policies, 1946-1955. In: Di Tella G, Dornbusch R (eds) The political economy of Argentina, 1946-1983. University of Pittsburgh Press, Pittsburgh, pp 59-88

Gerchunoff P, Fajgelbaum P (2006) Por qué Argentina no fue Australia? Una hipótesis sobre un cambio de rumbo. Siglo XXI, Buenos Aires

Germani G (1966) Mass immigration and modernization in Argentina. Stud Comp Int Dev 2(11):165-182

Germani G (1973) El surgimiento del peronismo: El rol de los obreros—y de los migrantes internos. Desarrollo Económico 13(51):435-488

Gibson EL (1997) The populist road to market reform: policy and electoral coalitions in Mexico and Argentina. World Polit 49(3):339-370

Glaeser EL, Ponzetto GAM, Shleifer A (2007) Why does democracy need education? J Econ Growth 12(2):77-99

Goel RK, Nelson MA (2005) Economic freedom versus political freedom: cross-country influences on corruption. Aust Econ Pap 44(2):121-133

Goldwert M (2014) Democracy, militarism, and nationalism in Argentina, 1930-1966: An interpretation. University of Texas Press, Austin

Golte J (1980) Repartos y rebeliones: Túpac Amaru y las contradicciones de la economía colonial. Instituto de Estudios Peruanos, Lima

Gomez I (2000) Declaring unconstitutional a constitutional amendment: the Argentine judiciary forges ahead. Univ Miami Inter-Am Law Rev 31(1):93-119

Gorodnichenko Y, Roland G (2011) Which dimensions of culture matter for long-run growth? Am Econ Rev 101(3):492-498

Guardado J (2016) Office-selling, corruption and long-term development in Peru. PhD diss., New York University

Guiso L, Sapienza P, Zingales L (2006) Does culture affect economic outcomes? J Econ Perspect 20(2):23-48

Gwartney JD, Lawson RA, Holcombe RG (1999) Economic freedom and the environment for economic growth. J Inst Theor Econ 155(4):643-663

Halperín Donghi T (1970) Historia contemporánea de América Latina. Alianza, Madrid

Halperín Donghi T (1991) The Buenos Aires landed class and the shape of politics in Argentina, 1820-1930. Center for Latin America Discussion Paper 85, University of Wisconsin-Milwaukee

Halperín Donghi T (1995) The Buenos Aires landed class and the shape of Argentine politics (1820-1930). In: Huber E, Safford F (eds) Agrarian structure and political power: landlord and peasant in the making of Latin America. University of Pittsburgh Press, Pittsburgh, pp 39-66

Halperín Donghi T (2004) La república imposible (1930-1945). Ariel, Buenos Aires

Hansen CB (2007) Asymptotic properties of a robust variance matrix estimator for panel data when $T$ is large. J Econom 141(2):597-620

Haring CH (1972) El imperio español en las Indias. Solar Hachette, Buenos Aires

Horowitz J (1990) Industrialists and the rise of Perón, 1943-1946: some implications for the conceptualization of populism. Americas 47(2):199-217

laryczower M, Spiller PT, Tommasi M (2002) Judicial independence in unstable environments, Argentina 1935-1998. Am J Polit Sci 46(4):99-716

IIsley LL (1952) The Argentine constitutional revision of 1949. J Polit 14(2):224-240

Jones MP, Saiegh S, Spiller PT, Tommasi M (2002) Amateur legislators-professional politicians: the consequences of partycentered electoral rules in a federal system. Am J Polit Sci 46(3):656-669

Kelly JM (1992) A short history of western legal theory. Oxford University Press, New York 
Kenn Farr W, Lord RA, Wolfenbarger JL (1998) Economic freedom, political freedom, and economic well-being: a causality analysis. Cato J 18(2):247-262

Kenworthy E (1975) Interpretaciones ortodoxas y revisionistas del apoyo inicial del peronismo. Desarrollo Económico 56(14):749-763

Kézdi G (2004) Robust standard errors estimation in fixed-effects models. Hung Stat Rev Spec 9:95-116

KloekT (1981) OLS estimation in a model where a microvariable is explained by aggregates and contemporaneous disturbances are equicorrelated. Econometrica 49(1):205-207

Knack S, Keefer P (1995) Institutions and economic performance: cross-country tests using alternative institutional measures. Econ Politics 7(3):207-227

Kovac M, Spruk R (2017) Persistent effects of colonial institutions on human capital formation and long-run development: local evidence from regression discontinuity design in Argentina. Presented at the Society for Institutional and Organizational Economics, Columbia University, New York

Krueger AO (2002) Political economy of policy reform in developing countries. MIT Press, Cambridge

Kydland FE, Zarazaga CEJM (2002) Argentina's lost decade. Rev Econ Dyn 5(1):152-165

La Porta R, López-de-Silanes F, Shleifer A (2008) The economic consequences of legal origins. J Econ Lit 46(2):285-332

Liang K-Y, Zeger SL (1986) Longitudinal data analysis using generalized linear models. Biometrika 73(1):13-22

Lipset SM (1959) Some social requisites of democracy: economic development and political legitimacy. Am Polit Sci Rev 53(1):69-105

Little W (1973) Electoral aspects of Peronism, 1946-1954. J Interam Stud World Aff 15(3):267-284

Llach JJ (1985) La Argentina que no fue, vol 1. Autores Editores, Buenos Aires

Lupu N, Stokes S (2010) Democracy, interrupted: regime change and partisanship in twentieth-century Argentina. Elect Stud 29(1):91-104

Lynch J (1955) Intendants and cabildos in the viceroyalty of La Plata, 1782-1810. Hisp Am Hist Rev 35(3):337-362

Maddison A (2007a) The world economy. Vol. 1: a millennial perspective. Organisation for Economic Co-operation and Development, Paris

Maddison A (2007b) The world economy. Vol. 2: historical statistics. Organisation for Economic Co-operation and Development, Paris

Mankiw NG, Romer D, Weil DN (1992) A contribution to the empirics of economic growth. Q J Econ 107(2):407-437

Manzetti L (1993) Institutions, parties, and coalitions in Argentine politics. University of Pittsburgh Press, Pittsburgh

Maravall JM, Przeworski A (eds) (2003) Democracy and the rule of law. Cambridge University Press, Cambridge

Marshall MG, Gurr TR, Jaggers K (2013) Polity IV project: political regime characteristics and transitions, 1800-2012. Center for Systemic Peace, Vienna

Maseland RKJ, Spruk R (2017) Premature democratization, premature deindustrialization. Paper presented at the Society for Institutional and Organizational Economics, Columbia University, New York

Matsushita H (1983) Movimiento obrero argentino, 1930-1945: Sus proyecciones en los orígenes del peronismo. Siglo Veinte, Buenos Aires

Mazzuca S (2007) Southern Cone Leviathans: state formation in Argentina and Brazil. PhD diss., University of California at Berkeley

McCloskey DN (2016) The humanities are scientific: a reply to the defenses of economic neo-institutionalism. J Inst Econ 12(1):63-78

Michels R (1911) Political parties: a sociological study of the oligarchic tendencies of modern democracy. Batoche, Kitchener

Miller J (1997) Judicial review and constitutional stability: a sociology of the US model and its collapse in Argentina. Hastings Int Comp Law Rev 21:77-126

Miller J (2003) A typology of legal transplants: using sociology, legal history and Argentine examples to explain the transplant process. Am J Comp Law 51(4):839-885

Mirow MC (2004) Latin American law: a history of private law and institutions in Spanish America. University of Texas Press, Austin

Mohtadi H, Roe TL (2003) Democracy, rent seeking, public spending and growth. J Public Econ 87(3-4):445-466

Molinelli NG, Palanza MV, Sin G (1999) Congreso, presidencia y justicia en Argentina. Temas, Buenos Aires

Montaño SMD (1957) The constitutional problem of the Argentine Republic. Am J Comp Law 6(2-3):340-345

Moreno Cebrián A (1976) Venta y beneficios de los corregimientos peruanos. Revista de Indias 36(143-44):213-246

Moulton BR (1986) Random group effects and the precision of regression estimates. J Econom 32(3):385-397

Moulton BR (1990) An illustration of a pitfall in estimating the effects of aggregate variables on micro units. Rev Econ Stat 72(2):334-338

Mukand S, Rodrik D (2015) The political economy of liberal democracy. Working Paper 21540, National Bureau of Economic Research, Cambridge, MA

Mukerjee A (2008) La negociación de un compromiso: la mita de las minas de plata de San Agustín de Huantajaya, Tarapacá, Perú (1756-1766). Bull I'Institut Français d'Études Andines 37(1):217-225

Munck R (1985) The 'Modern' military dictatorship in Latin America: the case of Argentina (1976-1982). Latin Am Perspect 12(4):41-74

Murmis M, Portantiero JC (1972) Estudios sobre los orígenes del peronismo, vol 2. Siglo XXI, Buenos Aires

Murphy KM, Shleifer A, Vishny RW (1993) Why is rent-seeking so costly to growth? Am Econ Rev 83(2):409-414

Negretto G (2009) Political parties and institutional design: explaining constitutional choice in Latin America. Br J Polit Sci 39(1):117-139

North DC (1990) Institutions, institutional change and economic performance. Cambridge University Press, Cambridge

North DC, Wallis JJ, Weingast BR (2009) Violence and social orders: a conceptual framework for interpreting recorded human history. Cambridge University Press, Cambridge

Nunn N, Puga D (2012) Ruggedness: the blessing of bad geography in Africa. Rev Econ Stat 94(1):20-36

Nunn N, Qian N (2011) The potato's contribution to population and urbanization: evidence from a historical experiment. Quart J Econ 126(2):593-650 
O'Connell A (1986) Free trade in one (primary producing) country: the case of Argentina in the 1920s. In: Di Tella G, Platt DCM (eds) The political economy of Argentina, 1880-1946. Palgrave Macmillan, London, pp 74-94

O'Donnell GA (1973) Modernization and bureaucratic-authoritarianism: studies in South American politics. University of California Press, Irvine

Olson M (1982) The rise and decline of nations: economic growth, stagflation, and social rigidities. Yale University Press, New Haven

Osiel MJ (1995) Dialogue with dictators: judicial resistance in Argentina and Brazil. Law Soc Inquiry 20(2):481-560

Ots Capdequí JM (1943) Manual de historia del derecho español en las Indias y del derecho propiamente indiano. Instituto de Historía del Derecho Argentino, Universidad de Buenos Aires, Buenos Aires

Owen F (1957) Perón: his rise and fall. Cresset Press, London

Pande R, Udry CR (2005) Institutions and development: a view from below. Economic growth center discussion paper 928, Yale University, New Haven, CT

Pellet Lastra A (2001) Historia Política de la Corte (1930-1990). AdHoc, Buenos Aires

Pemstein D, Meserve SA, Melton J (2010) Democratic compromise: a latent variable analysis of ten measures of regime type. Polit Anal 18(4):426-449

Pepper JV (2002) Robust inferences from random clustered samples: an application using data from the panel study of income dynamics. Econ Lett 75(3):341-345

Peralta-Ramos M (1992) The political economy of Argentina: power and class since 1930. Westview, Boulder

Pereira S (1983) En tiempos de la república agropecuaria (1930-1943). Centro Editor de América Latina, Buenos Aires

Pfeffermann D, Nathan G (1981) Regression analysis of data from a clustered sample. J Am Stat Assoc 76(375):681-689

Pigna F (2016) Miguel Juárez Celman y la revolución de 1890. El Historiador, Buenos Aires. https://www.elhistoriador.com. ar/miquel-juarez-celman-y-la-revolucion-de-1890/

Pion-Berlin D (1985) The fall of military rule in Argentina: 1976-1983. J Interam Stud World Aff 27(2):55-76

Platt DCM, Di Tella G (eds) (1985) Argentina, Australia and Canada: studies in comparative development, 1870-1965. Palgrave Macmillan, London

Potash RA (1996) The army and politics in Argentina, 1962-1973. Vol. 3. From Frondizi's fall to the peronist restoration. Stanford University Press, Stanford

Prado F (2009) In the shadows of empires: trans-imperial networks and colonial identity in Bourbon Rio de la Plata (c. 1750-c. 1813). PhD diss., Emory University

Prados de la Escosura L, Sanz-Villarroya I (2009) Contract enforcement, capital accumulation, and Argentina's long-run decline. Cliometrica 3(1):1-26

Przeworski A, Limongi F (1997) Modernization: theories and facts. World Polit 49(2):155-183

Psacharopoulos G (1994) Returns to investment in education: a global update. World Dev 22(9):1325-1343

Pucciarelli AR (1986) El capitalismo agrario pampeano, 1880-1930: La formación de una nueva estructura de clases en la Argentina moderna. Hyspamérica, Buenos Aires

Rennie YF (1945) The Argentine Republic. Macmillan, New York

Ribas AP (2000) Argentina, 1810-1880: Un milagro de la historia. VerEdit, Buenos Aires

Robinson JA (2013) measuring institutions in the trobriand islands: a comment on Voigt's paper. J Inst Econ 9(1):27-29

Rock D (1975) Politics in Argentina, 1890-1930: the rise and fall of radicalism. Cambridge University Press, Cambridge

Rock D (1987) Argentina, 1516-1987: from Spanish colonization to Alfonsín. University of California Press, Berkeley

Rock D (1993) Authoritarian Argentina: the nationalist movement, its history and its impact. University of California Press, Berkeley

Rodrik D (2016) Premature deindustrialization. J Econ Growth 21(1):1-33

Roe MJ (1998) Backlash. Columbia Law Rev 98(1):217-241

Romero RJ (1998) Fuerzas armadas: La alternativa de la derecha para el acceso al poder (1930-1976). Centro de Estudios Unión para la Nueva Mayoría, Buenos Aires

Romero LA (2013) A history of Argentina in the twentieth century, Rev edn. Pennsylvania State University Press, University Park

Rosa JM (1965) Historia Argentina, vol 1. Juan C. Granda, Buenos Aires

Rosenn KS (1990) The success of constitutionalism in the United States and its failure in Latin America: an explanation. Univ Miami Inter-Am Law Rev 22(1):1-39

Rouquié A (1982) Hegemonía militar, estado y dominación social. In: Rouquie A (ed) Argentina, hoy. Siglo XXI, Mexico City, pp 11-50

Sabato H (2001) On political citizenship in nineteenth-century Latin America. Am Hist Rev 106(4):1290-1315

Sábato JF (1988) La clase dominante en la Argentina moderna: Formación y características. CISEA, Buenos Aires

Sachs JD (1990) Social conflict and populist policies in Latin America. In: Brunetta R, Dell'Aringa C (eds) Labor relations and economic performance. Palgrave Macmillan, London, pp 137-169

Sachs JD, Malaney P (2002) The economic and social burden of malaria. Nature 415(6872):680-685

Saint Paul G, Verdier T (1996) Inequality, redistribution and growth: a challenge to the conventional political economy approach. Eur Econ Rev 40(3-5):719-728

Samuels D, Snyder R (2001) The value of a vote: malapportionment in comparative perspective. Br J Polit Sci 31(4):651-671

Sánchez-Alonso B (2000) Those who left and those who stayed behind: explaining emigration from the regions of Spain, 1880-1914. J Econ Hist 60(3):730-755

Sanguinetti HJ (1988) La democracia ficta, 1930-1938. Ediciones La Bastilla, Buenos Aires

Sanz-Villarroya I (2005) The convergence process of Argentina with Australia and Canada: 1875-2000. Explor Econ Hist 42(3):439-458

Sanz-Villarroya I (2007) La 'belle époque' de la economía Argentina, 1875-1913. Acciones e Investigaciones Sociales 23(1):115-138

Scartascini C, Tommasi M (2012) the making of policy: institutionalized or not? Am J Polit Sci 56(4):787-801

Schilizzi Moreno HA (1973) Argentina contemporánea: Fraude y entrega. Plus Ultra, Buenos Aires 
Shirley MM (2013) Measuring institutions: how to be precise though vague. J Inst Econ 9(1):31-33

Shumway N (1991) The invention of Argentina. University of California Press, Berkeley

Smith PH (1969) Social mobilization, political participation, and the rise of Juan Perón. Polit Sci Quart 84(1):30-49

Smith PH (1974) Argentina and the failure of democracy: conflict among political elites, 1904-1955. University of Wisconsin Press, Madison

Smulovitz C (1991) En busca de la fórmula perdida: argentina, 1955-1966. Desarrollo Económico 31(121):113-124

Snow PG (1965) Argentine radicalism: the history and doctrine of the radical civil union. University of lowa Press, Des Moines

Sokoloff KL, Engerman SL (2000) History lessons: institutions, factors, endowments, and paths of development in the new world. J Econ Perspect 14(3):217-232

Solberg CE (1987) The prairies and the pampas: Agrarian policy in Canada and Argentina, 1880-1930. Stanford University Press, Stanford

Spiller PT, Tommasi M (2003) The institutional foundations of public policy: a transactions approach with application to Argentina. J Law Econ Organ 19(2):281-306

Spinelli ME (2005) Los vencedores vencidos: El antiperonismo y la "revolución libertadora". Biblos, Buenos Aires

Spinesi L (2009) Rent-seeking bureaucracies, inequality, and growth. J Dev Econ 90(2):244-257

Spolaore E, Wacziarg R (2009) The diffusion of development. Quart J Econ 124(2):469-529

Spolaore E, Wacziarg R (2013) How deep are the roots of economic development? J Econ Lit 51 (2):325-369

Spruk R (2016) Institutional transformation and the origins of world income distribution. J Comp Econ 44(4):936-960

Sturzenegger F, Tommasi M (1994) The distribution of political power, the costs of rent-seeking, and economic growth. Econ Inq 32(2):236-248

Summerhill WR (2000) Institutional determinants of railroad subsidy and regulation in imperial Brazil. In: Haber S (ed) Political institutions and economic growth in Latin America: essays in policy, history and political economy. Hoover Institution Press, Stanford, pp 21-67

Szusterman C (1993) Frondizi and the politics of developmentalism in Argentina, 1955-62. Springer, New York

Tabellini G (2010) Culture and institutions: economic development in the regions of Europe. J Eur Econ Assoc 8(4):677-716

Taylor AM (1992) External dependence, demographic burdens, and Argentine economic decline after the Belle Époque. J Econ Hist 52(4):907-936

Taylor AM (1998a) Argentina and the world capital market: saving, investment, and international capital mobility in the twentieth century. J Dev Econ 57(1):147-184

Taylor AM (1998b) On the costs of inward-looking development: price distortions, growth, and divergence in Latin America. J Econ Hist 58(1):1-28

Taylor AM, Williamson JG (1997) Convergence in the age of mass migration. Eur Rev Econ Hist 1(1):27-63

Teichman J (1981) Interest conflict and entrepreneurial support for Perón. Latin Am Res Rev 16(1):144-155

Treier S, Jackman S (2008) Democracy as a latent variable. Am J Polit Sci 52(1):201-217

Vanhanen T (2000) A new dataset for measuring democracy, 1810-1998. J Peace Res 37(2):251-265

Vanhanen T (2003) Measures of democracy 1810-2002. Finnish Social Science Data Archive

Vittadini Andres SN (1999) First amendment influence in Argentine Republic law and jurisprudence. Commun Law Policy 4(2):149-175

Voigt S (2013) How (not) to measure institutions. J Inst Econ 9(1):1-26

Waisman CH (1987) Reversal of development in Argentina: postwar counterrevolutionary policies and their structural consequences. Princeton University Press, Princeton

Walter RJ (1969) The intellectual background of the 1918 university reform in Argentina. Hisp Am Hist Rev 49(2):233-253

Walter RJ (2002) The province of Buenos Aires and Argentine politics, 1912-1943. Cambridge University Press, Cambridge Weingast BR (1997) The political foundations of democracy and the rule of the law. Am Polit Sci Rev 91 (2):245-263

Wenzel NG (2010) Matching constitutional culture and parchment: post-colonial constitutional adoption in Mexico and Argentina. Hist Const 11:321-338

White H (1980) A heteroskedasticity-consistent covariance matrix estimator and a direct test for heteroskedasticity. Econometrica 48(4):817-838

White H (1984) Asymptotic theory for econometricians. Academic Press, New York

Wooldridge JM (2003) Cluster-sample methods in applied econometrics. Am Econ Rev 93(2):133-138

Wynia GW (1978) Argentina in the postwar era: politics and economic policy making in a divided society. University of New Mexico Press, Albuquerque

Yablón AS (2003) Patronage, corruption, and political culture in Buenos Aires, Argentina, 1880-1916. PhD diss., University of Illinois at Urbana-Champaign

Zakaria F (1997) The rise of illiberal democracy. Foreign Aff 2:22-43

Zorraquín Becú R (1978) La organización judicial Argentina en el período hispánico. Perrot, Buenos Aires

Zweimüller J (2000) Inequality, redistribution, and economic growth. Empirica 27(1):1-20

\section{Publisher's Note}

Springer Nature remains neutral with regard to jurisdictional claims in published maps and institutional affiliations. 